\title{
Potential role of probiotics in the management of gastric ulcer (Review)
}

\author{
GHALIA KHODER $^{1}$, ASMA A. AL-MENHALI ${ }^{2}$, FARAH AL-YASSIR $^{3}$ and SHERIF M. KARAM ${ }^{3}$ \\ ${ }^{1}$ Department of Pharmaceutics and Pharmaceutical Technology, College of Pharmacy, University of Sharjah, Sharjah 27272; \\ ${ }^{2}$ Department of Biology, College of Science; ${ }^{3}$ Department of Anatomy, College of Medicine and Health Sciences, \\ United Arab Emirates University, Al-Ain 17666, United Arab Emirates
}

Received October 25, 2015; Accepted March 3, 2016

DOI: 10.3892/etm.2016.3293

\begin{abstract}
Gastric ulcer is one of the most common chronic gastrointestinal diseases characterized by a significant defect in the mucosal barrier. Helicobacter pylori (H.pylori) infection and the frequent long-term use of non-steroidal anti-inflammatory drugs are major factors involved in gastric ulcer development. Acid inhibitors and antibiotics are commonly used to treat gastric ulcer. However, in the last few decades, the accumulating evidence for resistance to antibiotics and the side effects of antibiotics and acid inhibitors have drawn attention to the possible use of probiotics in the prevention and treatment of gastric ulcer. Probiotics are live microorganisms that when administered in adequate amounts confer health benefits on the host. Currently, the available experimental and clinical studies indicate that probiotics are promising for future applications in the management of gastric ulcers. This review aims to provide an overview of the general health benefits of probiotics on various systemic and gastrointestinal disorders with a special focus on gastric ulcer and the involved cellular and molecular mechanisms: i) Protection of gastric mucosal barrier; ii) upregulation of prostaglandins, mucus, growth factors and anti-inflammatory cytokines; iii) increased cell proliferation to apoptosis ratio; and iv) induction of angiogenesis. Finally, some of the available data on the possible use of probiotics in $H$. pylori eradication are discussed.
\end{abstract}

\section{Contents}

1. Introduction

2. Gastric ulcer

Correspondence to: Professor Sherif M. Karam, Department of Anatomy, College of Medicine and Health Sciences, United Arab Emirates University, Khalifa Street, Al-Ain 17666, United Arab Emirates

E-mail: skaram@uaeu.ac.ae

Key words: gastric mucosa, gastric mucosal barrier, gastric ulcer, probiotics, Helicobacter pylori, gastric ulcer prevention, gastric ulcer healing
3. Probiotics

4. Impacts of probiotics on systemic and gastrointestinal diseases

5. Prophylactic and therapeutic effects of probiotics in gastric ulcer

6. Effects of probiotics on H.pylori

7. Conclusions

\section{Introduction}

The gastric mucosa is lined by a single layer of epithelial cells that is supported by delicate elements of loose connective tissue underlaid by a thin layer of smooth muscle fibers. In many individuals, the gastric epithelium is exposed not only to its own acidic and enzymatic secretions, but also to duodenal bile, highly prevalent Helicobacter pylori $(H$. pylori), frequently used non-steroidal anti-inflammatory drugs (NSAIDs) and alcohol intake (1). Therefore, gastric mucosal damage is very common and may evolve into gastric ulcers in many patients. If not treated adequately, a gastric ulcer may lead to serious complications, such as perforation and bleeding, or may progress toward gastric cancer with substantial morbidity and mortality rates (2-4). Inhibition of acid secretion using proton pump inhibitors and eradication of $H$. pylori by treatment with clarithromycin, amoxicillin and metronidazole, are currently the most widely used therapeutic regimens for gastric ulcer (5). However, with the side effects of these therapeutic agents $(6,7)$, the emerging resistance of $H$. pylori to antibiotics $(8,9)$, and the high recurrence rate of gastric ulcer (10-12), efforts are being directed toward the identification of new therapeutic modalities.

With the increase of their popularity of use in the prevention and treatment of a number of systemic and gastrointestinal diseases (Fig. 1), probiotics have attracted the attention of numerous cell biologists and clinicians who are interested in exploring their effects on gastric ulcers and H.pylori. Even though the number of clinical studies investigating the impact of probiotics on gastric ulcer is relatively low, a number of experimental studies have generated promising results. The present review aims to summarize the available data concerning the potential role of probiotics in the prevention and healing of gastric ulcer. 


\section{Gastric ulcer}

Gastric ulcer is one of the most common and serious chronic diseases of the upper gastrointestinal tract. The prevalence of gastric ulcer is $2.4 \%$ in the Western population (13) and may be up to $6.1 \%$ in Asia (14). Despite advancements in anti-ulcer therapy, the recurrence rate remains high (10-12,15). A gastric ulcer is a localized deep necrotic lesion involving the entire mucosal thickness and the muscularis mucosa (16). It is generally considered that these ulcers develop from an imbalance between mucosal defensive mechanisms and damaging factors at the luminal surface of the stomach (1). In developing countries, the high prevalence of $H$. pylori, long-term frequent use of NSAIDs, and cigarette smoking represent the major risk factors involved in ulcer development $(17,18)$.

Ulcerogenesis starts by disruption of the protective mucous layer formed by the epithelial cells. Enhanced secretion of acid and pepsin by parietal and zymogenic cells may contribute to damage of the mucous layer (1). Smoking contributes to ulcer formation by upregulating the production of the proton pump and, therefore, acid secretion (19). Damage to the mucous layer may lead to peeling of the surface epithelium and exposure of the endothelial cells of capillaries in the underlying connective tissue. Once capillaries are damaged, oxygen and nutrients will be deficient. As a consequence, hypoxic necrosis will occur in deep glandular cells, namely stem/progenitor cells, mucous neck cells, zymogenic cells, enteroendocrine cells and parietal cells. Moreover, damaged macrophages, mast cells and endothelial cells release vasoactive agents and pro-inflammatory mediators that worsen the mucosal microcirculation. Epithelia and connective tissue necrosis eventually lead to the formation of ulcers $(1,20)$.

Healing of gastric ulcer involves an orchestrated array of different mechanisms that work together to correct the imbalance between damaging and defensive factors in the stomach (Fig. 2). Healing occurs by repairing the mucosal defect with epithelial cells and connective tissue elements, which involves the production of extracellular matrix, cell proliferation, migration, differentiation and gland reconstruction. These events are controlled by many factors, including epidermal growth factor, hepatocyte growth factor, insulin-like growth factor 1, trefoil factors, cyclooxygenase 2-generated prostaglandin, and several cytokines in a spatially and temporally coordinated manner (21). Healing also requires angiogenesis, which is triggered by hypoxia and involves vascular endothelial growth factor, fibroblast growth factor and angiopoietins (22). In addition to local mucosal cells from viable tissue at the ulcer edge, a study demonstrated that bone marrow-derived stem and progenitor cells are attracted to the site of injury and contribute to the regeneration of epithelial and connective tissue components (23). It has been proposed that the proliferation of these stem cells is followed by their commitment to different pathways and differentiation into parietal, surface mucous, mucous neck and zymogenic cells (24). Mucous neck cells are thought to be also involved in the healing of gastric ulcer $(25,26)$. They synthesize and secrete trefoil factor 2 , which downregulates acid secretion by parietal cells and, therefore, promotes mucosal healing (26).

Cell therapy may have some potential applications in gastric ulcer treatment. When bone marrow mesenchymal stem cells were injected (locally or intravenously) in rat models of gastric ulcer, they were found to promote ulcer healing $(27,28)$. However, the involved mechanisms are not known and this stem cell injection method remains to be evaluated. Other studies have demonstrated the possibility of gastric tissue engineering with the formation of all cell lineages or only mucous cells using freshly isolated gastric organoids, isolated gastric stem cells or gastric stem cell line (29-31). These promising studies require further evaluation and testing in animal models of gastric ulcers.

\section{Probiotics}

Numerous studies have indicated that probiotics can be used for the treatment of gastric ulcers. The idea of using probiotics arose from the study conducted by Elliott et al in 1998 (32). In a rat model of acetic acid-induced gastric ulcer, colonization of gram-negative bacteria occurred rapidly at the site of the ulcer and significantly impaired ulcer healing. However, colonization by gram-positive bacteria promoted ulcer healing. Notably, administration of the exogenous probiotic strain Lactobacillus accelerated ulcer healing (32).

Historically, the concept of probiotics began around 1900 by the Nobel laureate Elie Metchnikoff who discovered that the consumption of live bacteria (Lactobacillus bulgaricus) in yogurt or fermented milk improves the biological features of the gastrointestinal tract $(33,34)$. The Food and Agriculture Organization and the International Scientific Association for Probiotics and Prebiotics define probiotics as live microorganisms which, when administered in adequate amounts, confer a health benefit on the host (35).

The gut microbiota includes $\sim 30$ species of Bifidobacterium, 52 species of Lactobacillus, and others, such as Streptococcus and Enterococcus (36). The most extensively studied probiotics for treating and/or preventing gastrointestinal diseases are lactic acid bacteria, namely Lactobacillus and Bifidobacterium species. While these species are non-pathogenic, they can resist the harsh luminal environment of the gastrointestinal tract (37).

Several studies have revealed a number of beneficial effects of certain lactobacilli, such as the suppression of pathogenic bacteria in the gut and inhibition of allergic, inflammatory and neoplastic changes (38-41). Furthermore, it has been shown that lactobacilli are particularly useful in promoting gastric ulcer healing in rats, when administered as an individual probiotic strain, such as Lactobacillus rhamnosus GG (42), Lactobacillus gasseri OLL2716 $(43,44)$, or Lactobacillus acidophilus $(45,46)$ or as a probiotic mixture, VSL\#3 (47). Lactobacillus rhamnosus GG increases the cellular proliferation to apoptosis ratio and therefore promotes regeneration of epithelial cells, particularly at the ulcer margins $(42,48)$. In clinical studies, a probiotic mixture was demonstrated to be better than a single strain for improving the characteristics of indigenous microflora $(47,49)$. In addition to bacteria, certain yeasts, such as Saccharomyces boulardii, have been investigated and have shown potential therapeutic effects in a rat model of ibuprofen-induced gastric ulcer $(50,51)$. This yeast has neuraminidase activity, which removes sialic acid residues from the apical membranes of gastric epithelial cells. The loss of sialic acid prevents the adhesin-mediated binding of H. pylori to the epithelial cells (52). 


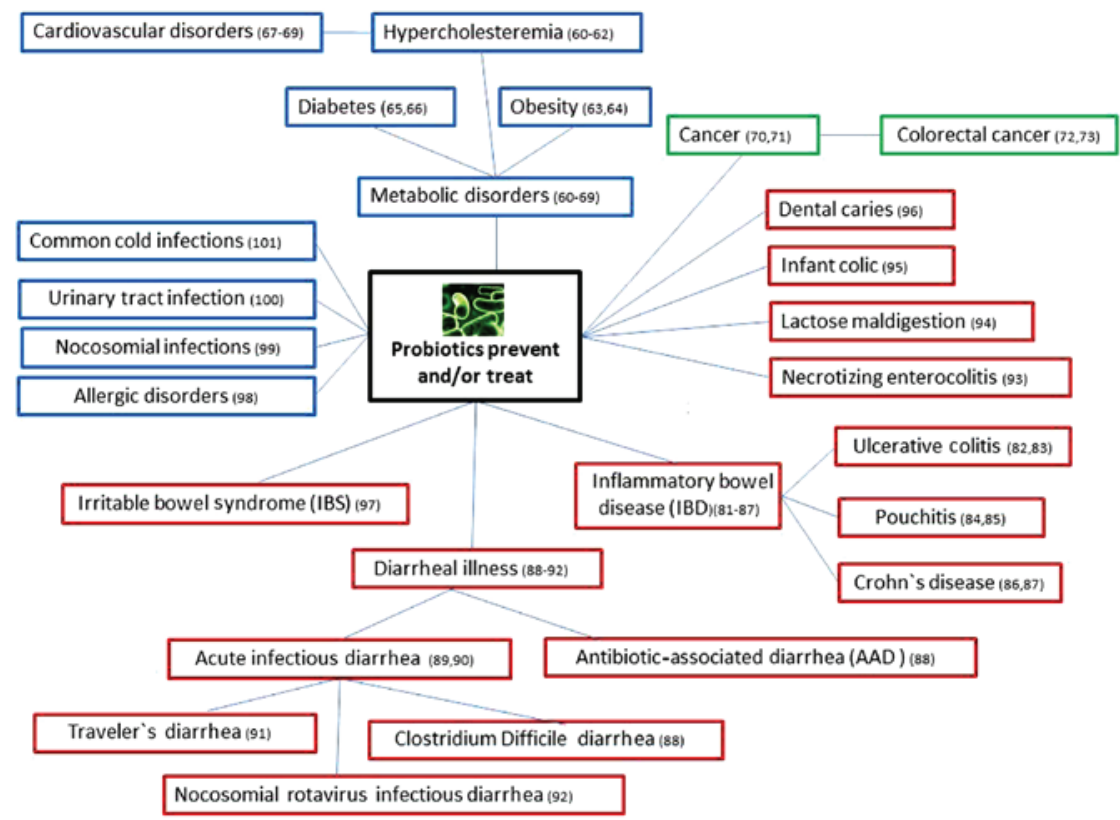

Figure 1. Summary of gastrointestinal (red), non-gastrointestinal (blue) and neoplastic (green) disorders that are currently known to respond to probiotics.

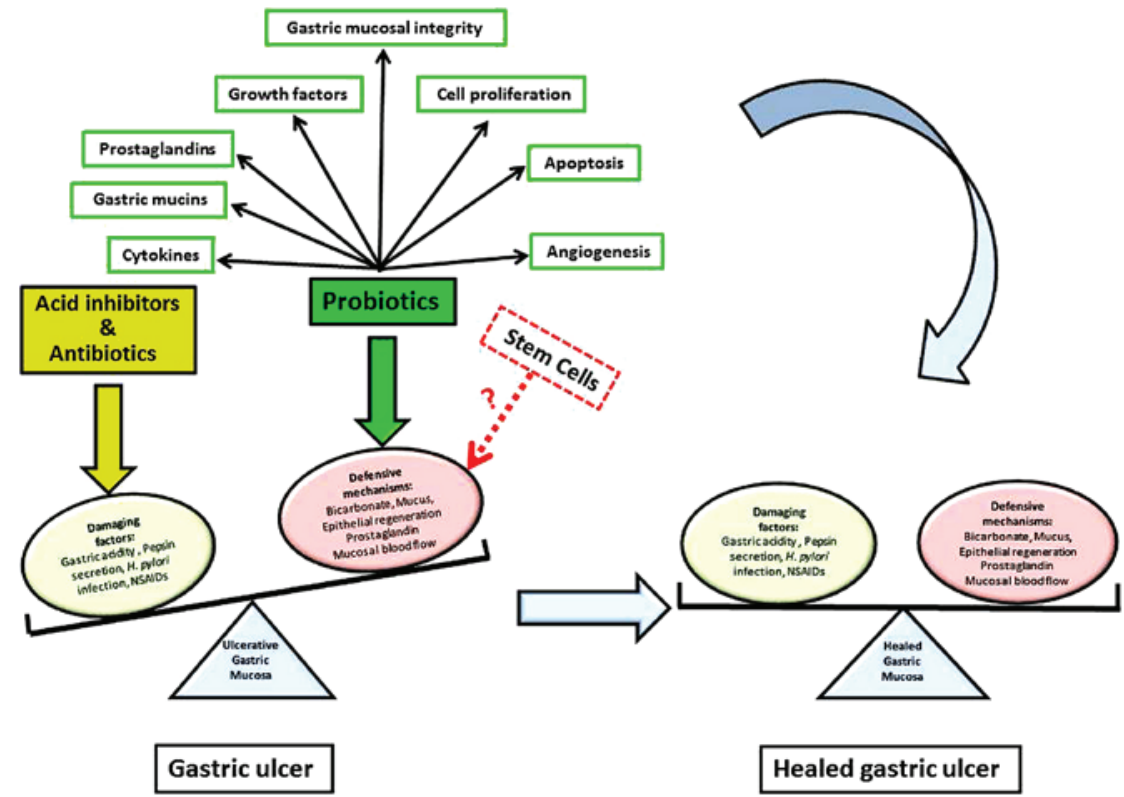

Figure 2. Summary of gastric ulcer etiology and different treatment options. Gastric ulcer results from the imbalance between damaging (gastric acidity, pepsin secretion, H. pylori infection and NSAIDS) and defensive factors (bicarbonate and mucus secretion, prostaglandin production, epithelial regeneration, and mucosal blood flow) of the mucosa. Acid inhibitors (e.g., proton pump inhibitors) and antibiotics specific for $H$.pylori (clarithromycin, amoxicillin/metronidazole) are used routinely for the treatment of gastric ulcer. Experimental studies suggest that probiotics could contribute to the prevention and therapeutic modalities of gastric ulcer by enhancing: i) Production of prostaglandin, mucins, growth factors and anti-inflammatory cytokines, ii) the cellular proliferation-to-apoptosis ratio, iii) gastric mucosal integrity, iv) trans-mucosal resistance and v) angiogenesis. Transplantation of bone marrow mesenchymal stem cells or possibly gastric epithelial stem cells is also a proposed modality for the treatment of gastric ulcers that requires further investigation. H.pylori, Helicobacter pylori; NSAIDs, non-steroidal anti-inflammatory drugs.

To date, $>13,438$ research articles on probiotics have appeared in PubMed and 1,422 articles were published during 2015 alone. Many of these articles report invaluable results demonstrating the effects of probiotics on the gastrointestinal tract using in vitro studies, animal models and healthy/unhealthy volunteers. The main gastrointestinal disorder targeted by probiotic research is irritable bowel syndrome (53-55). However, studies assessing the effects of probiotics on gastric ulcers are relatively limited. This could be due to the adverse physiological conditions of the host, such as an acidic environment, digestive enzymes, bile acids and mechanical stress that attenuate the survival and growth of certain probiotics. To overcome these conditions, a high dose of multiple probiotics has been administered $(47,56,57)$, and probiotics packaged into a suitable delivery system have been developed $(45,46)$. 
The beneficial effects of probiotics depend mainly on their ability to survive the acidic conditions and the hydrolytic enzymes and bile content in the stomach and duodenum (37). Several studies have shown that the strength of acidity, length of exposure and strain of probiotic are major factors affecting their survival (58-60). Among probiotic strains, lactic acid bacteria such as Lactobacillus and Bifidobacterium exhibit a great ability to survive gastric transit and, therefore, are extensively used in many pharmaceutical and dairy probiotic products.

Screening of different probiotics has revealed that Lactobacillus acidophilus and Bifidobacterium longum can survive and adhere better to the gastric mucosa than Streptococcus thermophilus and Bifidobacterium infantis/adolescentis/bifidum $(61,62)$. Studies have shown that Lactobacillus acidophilus survive at $\mathrm{pH} \geq 3$ after a 3 -h incubation (60) and Lactobacillus rhamnosus survive a 4-h incubation at pH 2.5 (63). Also, the viability of several strains of Lactobacillus acidophilus and Bifidobacterium was maintained for $\sim 3 \mathrm{~h}$ in the $\mathrm{pH}$ range of 1.5-3.0 (60). While the viability of a Bifidobacterium strain remains unchanged at a $\mathrm{pH}$ of 3 for $3 \mathrm{~h}$, which even declines slowly to $\mathrm{pH}$ of 2 or 1 after 1 h (59), Lactobacillus delbrueckii and Streptococcus thermophilus do not readily survive stomach acidity (64).

The reason underlying the survival of some probiotic strains in the stomach has been attributed to F-type ATPase. This bacterial membrane-bound ATP synthase is responsible for generating a constant gradient between extra- and intracellular $\mathrm{pH}$ for protection against acidic conditions (65). So, in an acidic environment, the $\mathrm{F}_{0} \mathrm{~F}_{1}$-ATPase is upregulated and generates a proton motive force via proton expulsion and, therefore, increases the intracellular $\mathrm{pH}$ (66). It has been reported that Lactobacillus acidophilus has a high cytoplasmic buffering capacity, which allows changes in cytoplasmic $\mathrm{pH}$ and stability in acidic conditions (67). Glucose enhances the survival of lactobacilli in acidic conditions because glycolysis provides ATP to $\mathrm{F}_{0} \mathrm{~F}_{1}$-ATPase, and thereby enables proton exclusion $(68,69)$.

To overcome the inability of some probiotics to survive, microencapsulated or coated probiotic strains have been developed (70-72). Recently, Villena and coworkers designed gastro-resistant tablets containing Lactobacillus fermentum CECT5716 using sodium alginate (73). Calcium alginate beads have also been proposed to protect the delivery of viable probiotic strains in the gastrointestinal tract $(74,75)$ and have even been used to treat cold restraint-induced gastric ulcers (46).

In addition to microencapsulation, coating and food supplements, the use of non-living probiotic strains could also contribute to overcoming the problem of acid-sensitive probiotic strains not surviving in the stomach. Even though some viable probiotic strains do not survive gastric transit, their dead forms remain beneficial (76). Substantial evidence from in vitro and animal studies has shown that both live and dead probiotics can act as biological response modifiers (76-78). Nonviable probiotics are now known as 'paraprobiotics' or 'ghost probiotics' (79).

Studies have shown that heat-killed Enterococcus faecalis fraction stimulates the gastrointestinal immune system against vancomycin-resistant enterococci (80) while heat-killed bifidobacteria induce significant increases in tumor necrosis factor (TNF)- $\alpha$ and interleukin (IL)-6 production (81). Using fractions of heat-killed Lactobacillus acidophilus and Lactobacillus casei, it is possible to protect immunodeficient mice against Candida albicans (82). Further studies have shown that even non-viable gamma ray-irradiated probiotic mixtures or their DNA can ameliorate the anti-inflammatory response in rats with experimental colitis (83). Also, it has been shown that viable and nonviable probiotic Lactobacillus paracasei IMPC2.1 and Lactobacillus rhamnosus GG can exert the same antiproliferative and proapoptotic effects on cancer cells in vitro (84).

\section{Impacts of probiotics on systemic and gastrointestinal diseases}

The prophylactic and therapeutic effects of probiotics in some gastrointestinal and non-gastrointestinal diseases are summarized in Fig. 1. In addition to their conventional benefits for gastrointestinal functions, probiotics have shown potential therapeutic effects in some metabolic diseases, such as hyperlipidemia or hypercholesterolemia $(85-89)$, obesity $(90,91)$ and diabetes $(92,93)$. Therefore, the use of probiotics may contribute to a reduced risk of atherosclerosis (94) and hypertension $(95,96)$.

In the last few decades, several studies have suggested a potential role for probiotics in cancer prevention and therapy (97). Data have shown specific alterations of the gut microbial composition (dysbiosis) in patients with colon cancer (98). Induction of colon cancer in rats using 1,2-dimethylhydrazine is associated with significant dysbiosis, which could be inhibited by the oral administration of Lactobacillus salivarius Ren, leading to effective suppression of colon carcinogenesis (99). In mice, treatment with the probiotics Clostridium butyricum and Bacillus subtilis has been found to inhibit the development of 1,2-dimethylhydrazine-induced colorectal cancer (100). As for gastric cancer, little is known about the possible association between probiotics and carcinogenesis. However, some in vitro studies have demonstrated very promising anti-proliferative and pro-apoptotic effects of probiotics on gastric cancer cells (84,101-104). Moreover, clinical studies have provided evidence for the possible effects of probiotics in preventing the toxic effects of chemotherapy and radiation therapy in cancer patients $(105,106)$.

The possible use of probiotics as supplements or even alternatives to oral antibiotic therapy has been suggested, especially with increasing cases of resistance to antibiotics. When frequently and unspecifically used, antibiotics may not only induce resistance, but also harm the gastrointestinal microflora. In these cases, the administration of probiotics may restore the normal microflora, compete with the pathogenic resistant bacteria and, therefore, help patients to recover $(107,108)$.

Novel approaches have been used to design some genetically modified probiotic strains with specific capabilities for the delivery of anti-inflammatory cytokines, vaccines and anti-pathogenic molecules (109-111). Engineered Lactococcus lactis strains were produced as live mucosal vaccines for a large number of antigens derived from bacteria, viruses and parasites (112). In addition, recombinant strains of Lactococcus lactis were used to produce the rotavirus spike-protein subunit VP8 that can prevent rotavirus infection (113). The future use 
of probiotics as vectors targeted to gastrointestinal mucosal lesions is promising. This new targeted drug delivery approach using probiotics is known as 'pharmabiotics' (35).

There are data suggesting that probiotics could be useful for gastrointestinal colic, acute infectious diarrhea, inflammatory bowel syndrome, antibiotic-associated diarrhea, travelers' diarrhea, lactose malabsorption and inflammatory bowel diseases $(85,86)$. However, the data available regarding the possible association between probiotic administration and gastric ulcer healing and prevention are limited.

\section{Prophylactic and therapeutic effects of probiotics in gas- tric ulcer}

Over the last two decades, the use of probiotics in the management of gastric ulcer has been investigated in a number of studies. Promising results for studies exploring both prophylactic (Table I) and therapeutic (Table II) effects of probiotics have been obtained. The studies concerning the roles of probiotics in gastric ulcer healing reported in the literature were mainly conducted in rats. These studies were based on the use of either individual probiotic strains, such as Lactobacillus rhamnosus GG (42,48), Lactobacillus gasseri OLL2716 (44), Lactobacillus acidophilus (45,46), Escherichia coli Nissle 1917 (114), Bifidobacterium animalis VKL/VKB (115), Bifidobacterium bifidum/brevis (116) and Saccharomyces boulardii (51), or a mixture of probiotic strains, such as VSL\#3 (47). A number of studies have reported that probiotics not only inhibit the development of acute gastric mucosal lesions, but also accelerate the process of healing of induced gastric ulcers $(42,44,47)$. The effects of probiotics on gastric ulcer are attributed to several cellular and molecular mechanisms (Fig. 3).

Protection of gastric mucosal barrier. In a normal stomach, the mucosal integrity is maintained by three main barriers $(117,118)$. i) The preepithelial barrier is made of a mucus-bicarbonate-phospholipid layer located between the gastric lumen and the epithelium. ii) The epithelial barrier characterized by a) a continuous sheet of surface epithelial cells connected by tight junctions and generating different secretory products including trefoil factors, prostaglandins, and heat shock proteins, and b) continuous cell renewal accomplished by proliferation of stem/progenitor cells and regulated by different mechanisms involving growth factors, prostaglandins, gastrin and the anti-apoptotic protein survivin. iii) The subepithelial barrier composed of a) microcirculation through capillaries maintained by the continuous generation of prostaglandins, nitric oxide and hydrogen sulfide that protect endothelial cells from injury and prevent aggregation of platelets and leukocytes, and b) sensory innervations that regulate the mucosal blood flow $(117,118)$.

When one or more of the above listed defensive mechanisms is altered, the gastric mucosal barrier is disrupted and a gastric ulcer may develop. The beneficial effects for probiotics on the gastrointestinal mucosa may occur via two main mechanisms (119-121). i) Antagonistic action achieved through lactic acid or antimicrobial compounds that inhibit the growth of pathogenic bacteria $(122,123)$ or by competing for the available nutrients and growth factors and, therefore, inhibit the growth of pathogens or block their adhesion to gastric epithelial cells $(124,125)$. ii) Immunomodulatory activity which involves the induction of phagocytosis, secretion of immunoglobulin A ( $\operatorname{Ig} \mathrm{A})$, activation of natural killer cells, stimulation of protective cytokines, downregulation of proinflammatory cytokines, and modulation of $\mathrm{T}$ cell responses (Th1 induction and Th2 attenuation) (126-129).

Probiotics can also protect the integrity of the gastric mucosal barrier by upregulating prostaglandin, mucous secretion, tight junction protein expression and cell proliferation, and by inhibiting apoptosis $(43,48,130-132)$. In rats, the administration of Bifidobacterium bifidum BF-1 or Bifidobacterium animalis VKL and VKB has been found to protect the gastric mucosa through either preventing the mucous barrier from degradation (115) or increasing gastric mucous production (133). The probiotic mixture VSL\#3 protects the epithelial barrier and upregulates the expression of tight junction proteins (occludin and zonula occludens-1) in vivo and in vitro via the activation of p38 or mitogen-activated protein (MAP) kinase and extracellular signal-regulated kinase (ERK) signaling pathways (134). Mennigen et al demonstrated that probiotics can strengthen the gastric mucosal barrier by inhibiting the redistribution and expression of tight junction proteins and blocking apoptosis (135). The probiotic strains Lactobacillus gasseri OLL2716, Lactobacillus rhamnosus GG and Escherichia coli Nissle 1917 are able to protect the altered gastric mucosal barrier $(43,48,114)$. In humans, Gotteland et al found that pretreatment with Lactobacillus GG protected against indomethacin-induced disruption of the gastric mucosal barrier (131).

Recently, three mouse models of induced gastric ulcers using alcohol, restraint cold stress and pyloric ligation were investigated. Pretreatment of these mice with the probiotic bacterial strain Clostridium butyricum alleviated the histopathological changes, specifically, the infiltration of inflammatory cells and gastric mucosal damage (136). Moreover, the same study showed that this bacterium alleviated oxidative stress damage by inhibiting the activity of superoxide dismutase and catalases and decreasing malondialdehyde levels. These results were similar to those obtained with omeprazole pretreatment (136).

Production of prostaglandins, growth factors and anti-inflammatory cytokines. Prostaglandins are involved in the ulcer healing process by inhibiting acid secretion, stimulating the production of mucus, bicarbonate and phospholipids, increasing blood flow and accelerating epithelial restitution (119). Therefore, prostaglandins are also thought to be a target for the prophylactic effect of probiotics in gastric ulcers $(43,48,114)$. Ethanol-induced gastric mucosal lesions in rats were prevented by pretreatment with the probiotic strain Lactobacillus rhamnosus GG through the upregulation of prostaglandin E2 (48). The effectiveness of the probiotic strain Escherichia coli Nissle 1917 in preventing stress-induced ulcers in rats has also been reported. This effect was achieved through induction of mucosal anti-inflammatory cytokines, synthesis of gastric mucosal protective factors (ghrelin and heat shock protein 70), enhancement of gastric microcirculation, and involvement of prostaglandins and nitric oxide (114).

Uchida and Karakazu demonstrated that pretreatment of rats with LG21 yogurt containing Lactobacillus gasseri 


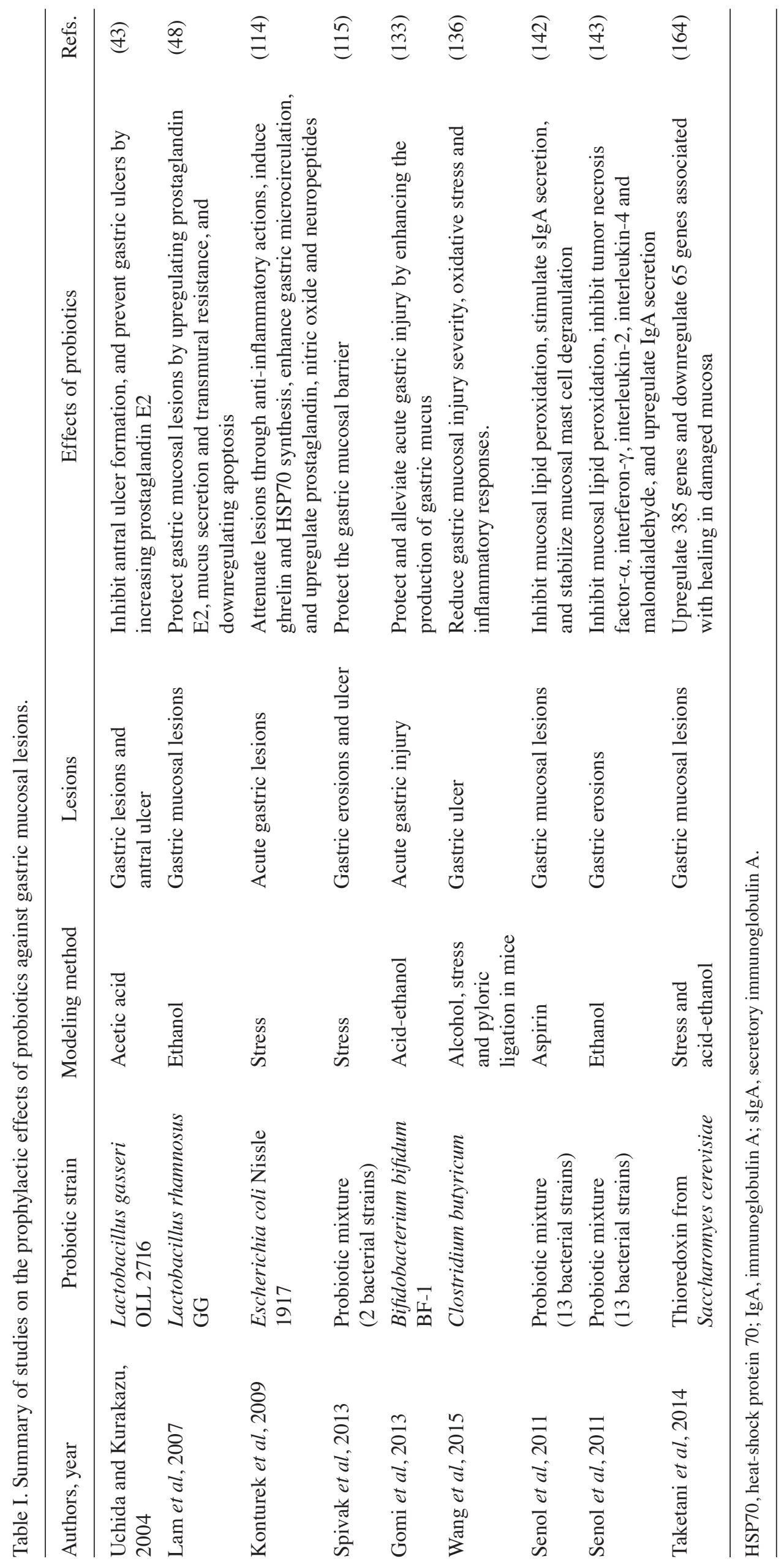




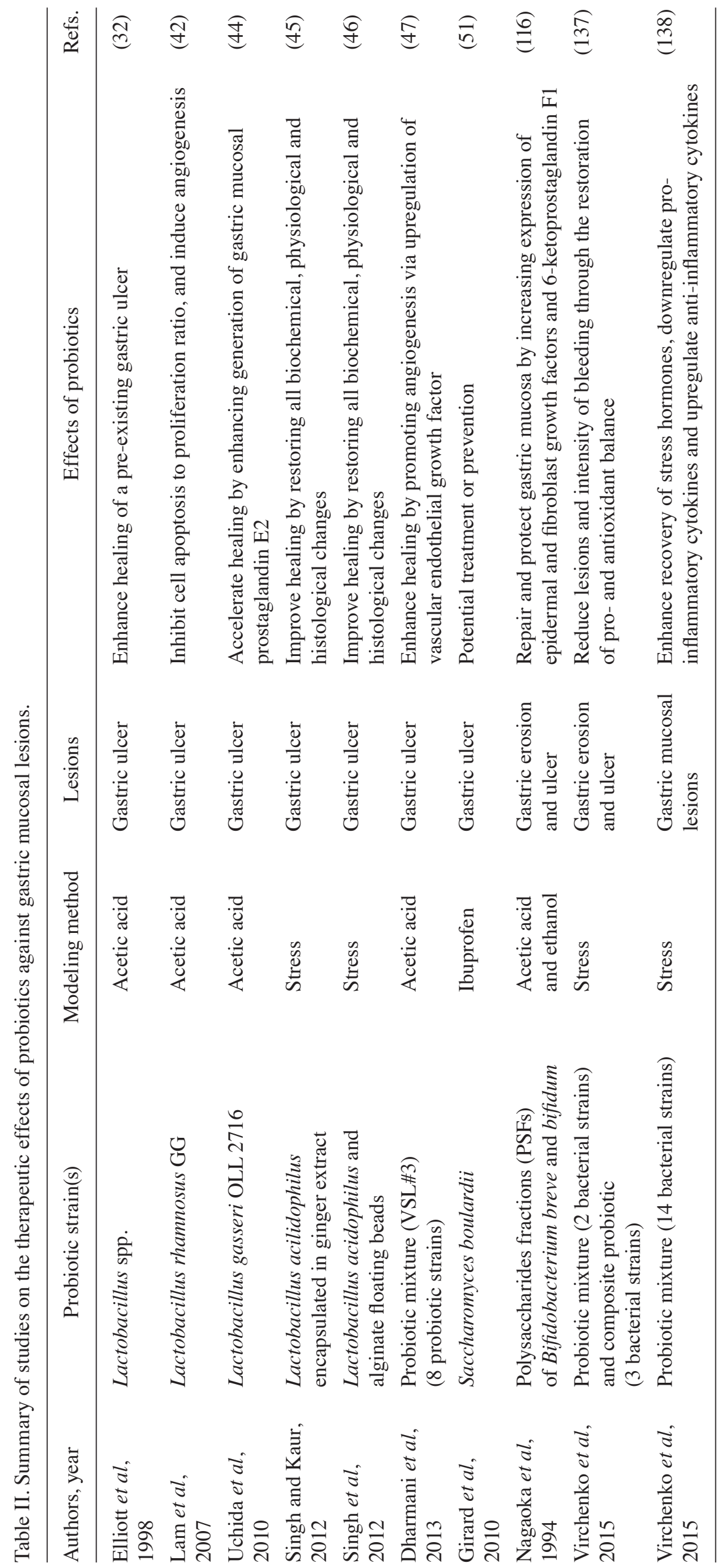




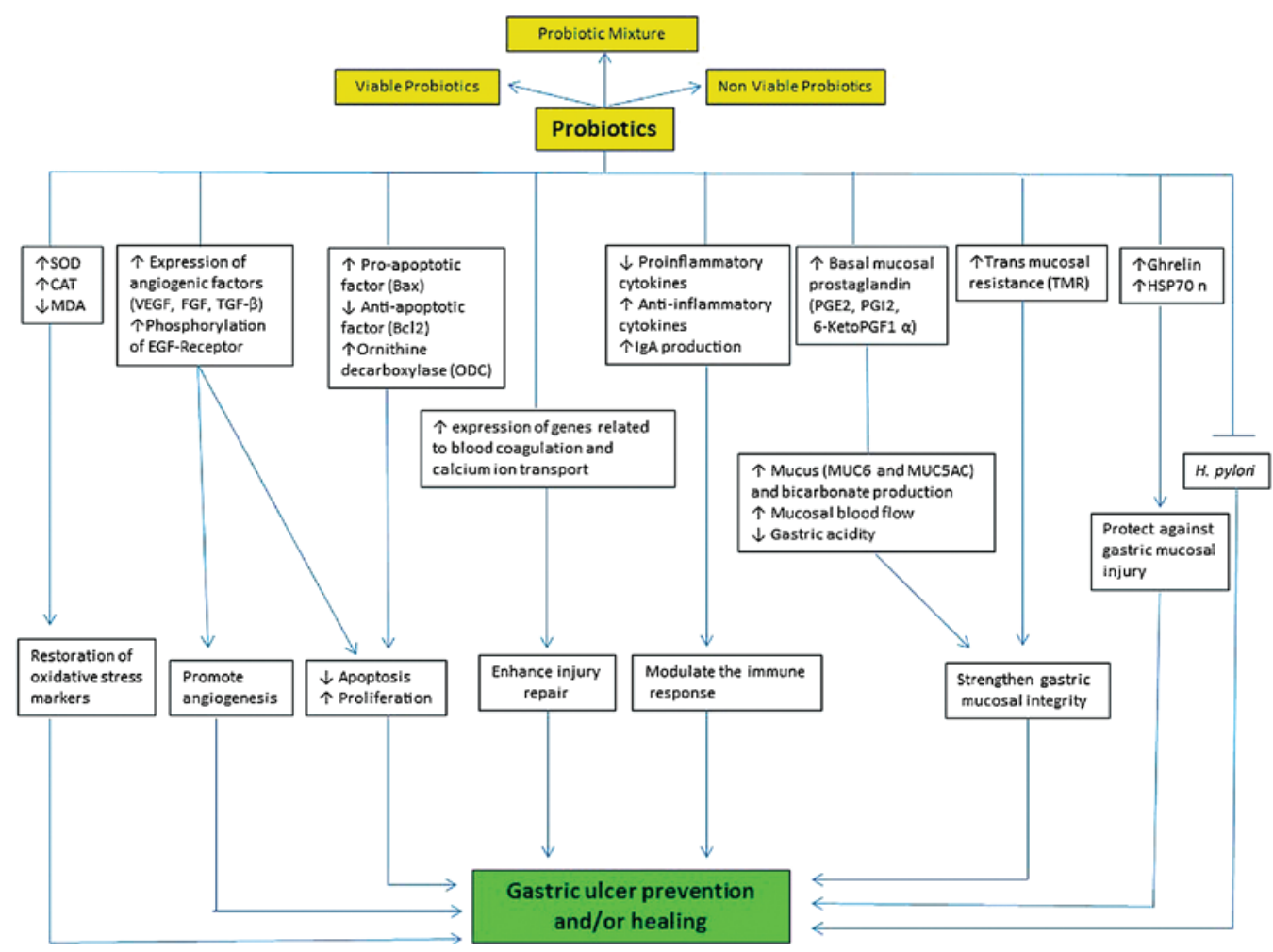

Figure 3. Summary of the proposed main cellular and molecular events involved in the effects of probiotics on gastric ulcer.SOD, superoxide dismutase; CAT, catalase; MDA, malondialdehyde; VEGF, vascular endothelial growth factor; FGF, fibroblast growth factor; TGF, transforming growth factor; EGF, epidermal growth factor; Bax, Bcl-2-associated X protein; Bcl2, B cell lymphoma 2; IgA, immunoglobulin A; PGE2, prostaglandin E2; PGI2, prostaglandin I2; PGF1 $\alpha$, prostaglandin F1 $\alpha$; HSP70, heat-shock protein 70; MUC6, mucin 6; MUC5AC, mucin 5AC.

OLL2716 significantly inhibited the formation of acetic acid-induced gastric ulcers in a dose dependent manner. This effect was mediated by increasing the production of mucosal prostaglandin E2/I2. Notably, the gastro-protective effect of prostaglandin was attenuated by pretreatment of the rats with indomethacin, which is known to inhibit prostaglandin (43). A few years later, the same authors demonstrated that the administration of the same Lactobacillus gasseri OLL2716 yogurt for 10 days significantly accelerated the healing of chronic gastric ulcers through the stimulation of prostaglandin production (44). However, yogurt containing gamma-ray-exposed Lactobacillus gasseri OLL2716 increased the generation of prostaglandin without affecting the healing of the acetic acid-induced gastric ulcers. These findings indicate that the increased production of prostaglandin does not necessarily explain the therapeutic effect of LG21 yogurt on ulcer healing (44). Recently, pretreatment with the probiotic Clostridium butyricum in mouse models of induced gastric ulcer caused a reduction in the level of 6-keto-prostaglandin F1 $\alpha$, the stable metabolite of prostaglandin I2 (136).

Aside from the probiotic bacteria itself, the polysaccharide fractions can also exert a gastroprotective effect against gastric ulcers. Nagaoka et al demonstrated that polysaccharides of Bifidobacterium breve YIT4014 and 4043I and Bifidobacterium bifidum YIT4007 were able to repair and protect the mucosa of rats against acetic acid- and ethanol-induced gastric ulcers and erosions. The polysaccharides of these probiotic mixtures were found to increase the expression of growth factors such as fibroblast growth factor and epidermal growth factor in addition to 6-ketoprostaglandin F1 (116).
Recent studies on stress-induced gastric mucosal lesions demonstrated that using a mixture of probiotics (Lactobacillus, Lactococcus, Bifidobacterium, Propionibacterium and Acetobacter) enhanced ulcer healing by restoring the balance between pro- and anti-oxidants in the gastric mucosa (137). In addition, probiotic mixtures (comprising Bifidobacterium animalis VKL and VKB with or without Lactobacillus casei IMVB-7280) enhanced the recovery of stress hormones (adrenocorticotropin and corticosterone), decreased proinflammatory cytokines and increased anti-inflammatory cytokines (138). Moreover, pretreatment with Clostridium byturicum attenuated the elevation of proinflammatory factors (IL-1 $\beta$, TNF- $\alpha$ and leukotriene B4) in mice with induced gastric ulcer (136).

Probiotics are not only effective against gastric ulcers induced by acetic acid, ethanol or stress, but also play important roles in the prevention or treatment of ulcers induced by NSAIDs, such as aspirin or indomethacin (139). In aspirin-treated rats, TNF upregulates neutrophil-derived superoxide leading to oxygen radical-mediated tissue damage $(140,141)$. Thus, this pro-inflammatory cytokine is an ideal target for protection against gastric ulcer. In this context, using a rat model of asprin-or ethanol-induced gastric mucosal damage, it was found that using a probiotic mixture of 13 bacterial strains composed of four strains of Lactobacillus fermentum (BB16-75, AK2-8, AK5-22, AK6-26), three strains of Lactobacillus plantarum (AA17-73, AK7-28, AK8-31B) and six strains of Enterococcus faecium (AB6-21, AB16-68, AK4-120, AK7-31, BK9-40, BK13-54) caused a reduction in mucosal damage scores, lipid peroxidation, malondialdehyde 
content and pro-inflammatory cytokine levels. In addition, these probiotics also induced an increase in mucosal secretory Ig A production and the stabilization of mucosal mast cells $(142,143)$.

Production of gastric mucus. Mucus is a cohesive mixture of $95 \%$ water, 5\% mucin glycoprotein molecules, salts, immunoglobulins, cellular and serum macromolecules, and trefoil peptides $(144,145)$. Mucus on the luminal surface of gastric mucosa forms two main layers: The outer loosely adherent mucus and the inner firmly adherent mucus. The former plays a role in binding luminal noxious agents, absorbing nitrite and releasing nitric oxide. The latter is important for protection against digestive enzymes and corrosive acid (146).

There are several mucin genes encoding secreted and transmembrane mucins, such as MUC1, MUC2, MUC3, MUC4, MUC5AC, MUC5B, MUC6-8, MUC11, MUC12 and MUC16. The stomach has two distinct cell types secreting different mucins: Surface mucus cells secreting MUC5AC and mucus neck cells secreting MUC6 (147). Transmembrane mucins (MUC1, MUC4 and MUC16) are mainly involved in signal transduction and cell adhesion phenomena (148). Another noteworthy class of secretory proteins is the trefoil peptides. These are produced and secreted together with mucins, and thus are present in fairly high concentrations in the mucous gel layer and in the mucosal epithelial cells (145). They are intimately associated with mucus to improve protection against noxious agents. They are upregulated during mucosal injury and have been implicated in promoting cell migration and the repair process (149-151).

The mucus layer protects the gastric mucosa by different mechanisms (152,153): i) Acting as a physical barrier, ii) binding to bacterial adhesins, iii) maintaining high concentrations of secreted IgA and lysozyme at the epithelial surface, iv) acting as a free radical scavenger, and v) delaying proton permeation from the luminal acid into gastric surface cells to enable its neutralization by secreted bicarbonate. Therefore, while the gastric mucus protects the gastric epithelial cells, it also helps in the protection and survival of microflora.

Some studies have shown that probiotics promote mucous secretion. Treatment of colonic epithelial Caco-2 cells or colorectal HT29 cells with probiotics increased the expression of mucins (154-156). Administration of VSL\#3 to rats for 7 days was enough to induce a 60 -fold increase in MUC2 expression and its concomitant secretion (157). Probiotics can also adhere to mucus via specific binding proteins and eventually modulate the immune system for protection against pathogens $(158,159)$. In the stomach, the available studies on the effects of probiotics on mucous production have demonstrated different results. Pretreatment with Bifidobacterium BF-1 upregulates MUC5AC gene expression and enhances the production of mucus by surface mucous cells in rats with acute gastric lesions induced by acid/ethanol (133). However, the expression of MUC5AC was moderately upregulated or unchanged, respectively, in VSL\#3- or Lactobacillus rhamnosus GG-treated rats with ethanol-induced gastric mucosal lesions $(47,48)$. Even though the MUC5AC gene is responsible for the most abundantly produced mucin in the normal mucosa, Lam and colleagues reported that pretreatment of rats with Lactobacillus rhamnosus GG caused upregulation of MUC6 mRNA expression (specific for mucous neck cells) in gastric mucosal lesions induced by ethanol (48). Moreover, it was demonstrated that pretreatment with a probiotic mixture (Bifidobacterium animalis VKL and VKB) in rats with stress-induced gastric mucosal erosion and ulcer, prevented degradation of the mucous layer (115).

Cell proliferation and apoptosis. Perpetual cell renewal is an important epithelial factor required for the maintenance of the gastric mucosal barrier. The dynamics and cells involved in this physiological phenomenon have been defined in rodents and humans $(160,161)$. Several factors and cell types in the corpus region of the stomach are involved in the regulation of this renewal process including enteroendocrine cells (Karam and Al-Menhali, unpublished data) and parietal cells (162). Some studies have also explored the effects of probiotics on cellular proliferation and apoptosis. Pretreatment of rats with Lactobacillus rhamnosus GG significantly reduced the number of apoptotic cells in ethanol-induced gastric mucosal lesions (48). The reduction of apoptosis is controlled by upregulation of the anti-apoptotic protein, B cell lymphoma 2 (42). Further investigations revealed that the same Lactobacillus probiotic strain not only inhibits the apoptosis of gastric mucosal cells, but also stimulates gastric cell proliferation, which is mediated by ornithine decarboxylase (42).

Angiogenesis. Induction of angiogenesis is one of the most important effects of probiotics on gastric ulcers $(42,47)$. Vascular endothelial growth factor is required to stimulate the formation of granulation tissue and development of new microvessels (163). Administration of the probiotic mixture VSL\#3, composed of eight probiotic strains: four Lactobacilli (acidophilus, bulgaricus, casei and plantarum), three Bifidobacteria (breve, infantis and longum) and Streptococcus accelerates gastric ulcer healing in a rat model by upregulating the expression and production of vascular endothelial growth factor. This ulcer-healing effect was confirmed using neutralizing antibodies (47). In another study, administration of the probiotic strain Lactobacillus rhamnosus GG to rats with acetic acid-induced gastric ulcers led to a significant increase in the number of blood microvessels (42). Notably, this angiogenic effect was observed only at the edge of damaged gastric mucosa and not in the surrounding normal tissues. Therefore, Lactobacillus rhamnosus GG is a potential therapeutic agent for promoting vascularization and gastric ulcer healing and requires further clinical investigation.

Since the harsh physiological conditions in the stomach may interfere with the colonization of some probiotic strains, efforts have been directed toward packing probiotics into a suitable delivery system. A novel synbiotic approach using Lactobacillus acidophilus encapsulated with ginger extract (45) or loaded in alginate floating beads (46), significantly enhanced the healing of gastric stress-induced ulcers in rats. This was evidenced by the restoration of various biochemical (lipid peroxidation, catalase and superoxide dismutase), physiological (mucous content) and histological (ulcer index and hemorrhagic streaks) changes. Moreover, histopathological studies have indicated that the administration of Lactobacillus acidophilus encapsulated with ginger extract leads to complete recovery from gastric ulcer with no 
signs of inflammation or mucosal damage visible at the ulcer edge $(45,46)$.

The effects of probiotics on angiogenesis are not restricted to bacterial strains. Yeast, such as Saccharomyces boulardii, has been reported to have potential in the treatment and prevention of gastric ulcer induced by ibuprofen in rats (51). More recently, it was demonstrated using DNA microarray that thioredoxin derived from edible yeast, Saccharomyces cerevisiae, can protect the gastric mucosa by up- or downregulating hundreds of genes involved in the healing of the ulcerative mucosa induced by stress or $\mathrm{HCl} /$ ethanol in rats (164).

\section{Effects of probiotics on $\mathrm{H}$. pylori}

For a long time, gastric ulcers were considered to be a result of stress, improper diet and NSAID usage. However, the discovery of $H$. pylori and its association with gastric ulcers has changed the gastroenterological practice worldwide (165). $H$. pylori can uniquely survive and colonize in the harsh acidic environment of the stomach for decades, leading to progressive inflammatory, ulcerative and neoplastic changes (166). Among patients infected by $H$. pylori, 10-20\% may ultimately develop ulcers (16). Recent regression of ulcer incidence is highly dependent on the worldwide eradication of $H$. pylori (167).

Eradication of $H$. pylori and associated gastric mucosal changes remain a challenge for gastroenterologists. This could be due to the fact that $H$.pylori infection may start early during childhood where developing gastric glands are characterized by prominent dividing stem cells (Karam and Bharwani, unpublished data). No antibiotic is effective enough to eliminate $H$. pylori when given as a monotherapy. The gold standard triple regimen (clarithromycin and amoxicillin/metronidazole combined with a proton pump inhibitor) represents the worldwide accepted protocol used in the eradication of $H$. pylori. Studies using this triple therapy have demonstrated an eradication rate of $90 \%$ (168). However, none of the studies reported $100 \%$ eradication of $H$. pylori.

In some countries, the marked rise in resistance to clarithromycin has caused a steady decline in the efficiency of the standard triple therapy $(169,170)$. To overcome this problem, new regimens including quadruple, sequential, concomitant, dual and rescue therapies have been introduced (168). However, the development of resistance to antibiotics and their side effects has caused poor patient compliance and, therefore, has limited their applications (171).

During the last decade, numerous studies have explored the possible use of probiotics to improve the protocol of H. pylori eradication and to prevent its side effects (172-176). The use of probiotics has also been tested in asymptomatic H.pylori-infected patients and found to lower the risk of gastric ulcer development (177). Kabir and co-workers were one of the first groups to report that probiotic strain Lactobacillus salivarus can prevent and eliminate $H$. pylori colonization in the stomach of gnotobiotic BALB/c mice (178).

On the basis of in vitro studies using gastric epithelial cells and different probiotic strains, several effects for probiotics against $H$. pylori infection have been identified (179). Probiotics can inhibit $H$. pylori infection by non-immunological and immunological mechanisms (179-181). The non-immunological effects of probiotics include: i) Production of antimicrobials and antioxidants that could inhibit either the growth or urease activity of $H$.pylori $(182,183)$, ii) competing with $H$. pylori for binding to the surface of gastric epithelial cells and blocking their specific membrane receptors (125,184-186), and iii) stabilizing the gastric mucosal barrier by stimulating mucus production by surface epithelial cells (187).

The immunological effects of probiotics include: i) Maintaining the balance between pro- and anti-inflammatory cytokines, which leads to recovery from gastritis (188), ii) downregulating the production of IL- 8 and TNF- $\alpha$ by producing conjugated linoleic acid that targets the nuclear factor $\kappa \mathrm{B}$ pathway $(189,190)$, iii) upregulating the anti-inflammatory suppressor of cytokine signaling through activation of signal transducer and activator of transcription (STAT)-1/STAT-3 transcription factors and inactivation of Janus kinase 2 (191), and iv) enhancing gastric mucosal barrier by stimulating $\operatorname{Ig} \mathrm{A}$ secretion and transport (181).

In animal models of $H$. pylori infection and also in humans, the use of different probiotic strains has demonstrated different favorable effects, specifically, prophylaxis against $H$. pylori, inhibition of $H$. pylori colonization, and alleviation of $H$.pylori-associated gastric inflammation $(173,181,192,193)$. Therefore, some clinical and laboratory-based studies have demonstrated an improvement in $H$. pylori eradication by using probiotics $(194,195)$.

The most frequently used probiotic strains for $H$. pylori infection are Lactobacillus johnsonii La1 (177,196,197). Lactobacilli, the predominant gut bacteria, inhibit adhesion of $H$. pylori to gastric epithelial cells in vitro. Thus, using lactobacilli exogenously can help in the eradication of $H$. pylori. Other probiotic strains such as Saccharomyces boulardii, Lactobacillus acidophilus and Bifidobacterium lactis, have been used either alone or combined with antibiotics specific to $H$. pylori. Meta-analytic studies have recommended the use of either Saccharomyces boulardii or Lactobacillus species supplementation in combination with the standard triple therapy $(198,199)$.

Some in vitro studies demonstrating the inhibition or even killing of $H$. pylori by probiotics have been followed by preclinical and clinical applications $(200,201)$. These studies indicated only a partial efficacy of probiotics against $H$. pylori when administered alone. Increase of efficacy and/or reduction of side effects was demonstrated when probiotics were administered in combination with the standard triple treatment of $H$. pylori (201). However, to date, there is no study that demonstrates complete eradication of $H$. pylori infection by probiotic treatment.

\section{Conclusions}

Gastric ulcers develop due to an imbalance between damaging factors and the defense mechanisms of the gastric mucosa (Fig. 2). The available studies in the literature indicate that probiotics can accelerate the healing of gastric ulcers via multiple mechanisms that involve both damaging and defensive factors (Fig. 2). Even though only limited in vivo studies have explored the impact of probiotics in gastric ulcer, some cellular and molecular findings have suggested their protective and therapeutic effects (Fig. 2). Several studies also identified 
probiotic strains effective in $H$. pylori eradication via immunological and non-immunological mechanisms. Therefore, the use of probiotics in the management of gastric ulcer appears promising and further studies are required. Taking in consideration the probiotic strains, dosage, commercial preparations and the heterogeneity of patients, a combined clinical and basic science experimental approach is likely to yield important strategies to optimize the use of probiotics in health and disease (202).

\section{Acknowledgements}

This study is supported by the Emirates Foundation, Grant no. 2010/146 and The Sheikh Hamdan Award, Grant no. MRG50/2011-12.

\section{References}

1. Tarnawski A, Ahluwalia A and Jones MK: Gastric cytoprotection beyond prostaglandins: Cellular and molecular mechanisms of gastroprotective and ulcer healing actions of antacids. Curr Pharm Des 19: 126-132, 2013.

2. Lau JY, Barkun A, Fan DM, Kuipers EJ, Yang YS and Chan FK: Challenges in the management of acute peptic ulcer bleeding. Lancet 381: 2033-2043, 2013.

3. Hwang JJ, Lee DH, Lee AR, Yoon H, Shin CM, Park YS and Kim N: Characteristics of gastric cancer in peptic ulcer patients with Helicobacter pylori infection. World J Gastroenterol 21: 4954-4960, 2015.

4. Taş İ, Ülger BV, Önder A, Kapan M and Bozdăg Z: Risk factors influencing morbidity and mortality in perforated peptic ulcer disease. Ulus Cerrahi Derg 31: 20-25, 2014.

5. Malfertheiner P: Helicobacter pylori infection-management from a European perspective. Dig Dis 32: 275-280, 2014.

6. Wallace JL, Syer S, Denou E, de Palma G, Vong L, McKnight W, Jury J, Bolla M, Bercik P, Collins SM, et al: Proton pump inhibitors exacerbate NSAID-induced small intestinal injury by inducing dysbiosis. Gastroenterology 141: 1314-1322.e5, 2011.

7. Karam SM and Forte JG: Inhibiting gastric $\mathrm{H}(+)-\mathrm{K}(+)-A T P a s e$ activity by omeprazole promotes degeneration and production of parietal cells. Am J Physiol 266: G745-G758, 1994.

8. Ghotaslou R, Leylabadlo HE and Asl YM: Prevalence of antibiotic resistance in Helicobacter pylori: A recent literature review. World J Methodol 5: 164-174, 2015.

9. Howden CW, Chey WD and Vakil NB: Clinical rationale for confirmation testing after treatment of Helicobacter pylori infection: Implications of rising antibiotic resistance. Gastroenterol Hepatol (NY) 10 (7 Suppl 3): S1-S19, 2014.

10. Tarnawski A, Hollander D, Krause WJ, Dabros W, Stachura J and Gergely H: 'Healed' experimental gastric ulcers remain histologically and ultrastructurally abnormal. J Clin Gastroenterol 12 (Suppl 1): S139-S147, 1990.

11. Watanabe T, Higuchi K, Tominaga K, Fujiwara Y and Arakawa T: Acid regulates inflammatory response in a rat model of induction of gastric ulcer recurrence by interleukin 1beta. Gut 48: 774-781, 2001.

12. Arakawa T, Watanabe T, Tanigawa T, Tominaga K, Fujiwara Y and Morimoto K: Quality of ulcer healing in gastrointestinal tract: Its pathophysiology and clinical relevance. World J Gastroenterol 18: 4811-4822, 2012.

13. Groenen MJ, Kuipers EJ, Hansen BE and Ouwendijk RJ: Incidence of duodenal ulcers and gastric ulcers in a Western population: Back to where it started. Can J Gastroenterol 23: 604-608, 2009.

14. Sung JJ, Kuipers EJ and El-Serag HB: Systematic review: The global incidence and prevalence of peptic ulcer disease. Aliment Pharmacol Ther 29: 938-946, 2009.

15. Fujino S, Suzuki Y and Tanaka T: Cost-benefit analysis of medicinal treatment for gastric ulcers. Long-term model including healing and recurrence. Health Policy 5: 45-72, 1985.

16. Malfertheiner P, Chan FK and McColl KE: Peptic ulcer disease. Lancet 374: 1449-1461, 2009.
17. Hirayama F, Takagi S, Kusuhara H, Iwao E, Yokoyama Y and Ikeda Y: Induction of gastric ulcer and intestinal metaplasia in mongolian gerbils infected with Helicobacter pylori. J Gastroenterol 31: 755-757, 1996.

18. Wang GZ, Huang GP, Yin GL, Zhou G, Guo CJ, Xie CG, Jia BB and Wang JF: Aspirin can elicit the recurrence of gastric ulcer induced with acetic acid in rats. Cell Physiol Biochem 20: 205-212, 2007

19. Hammadi M, Adi M, John R, Khoder GA and Karam SM: Dysregulation of gastric H,K-ATPase by cigarette smoke extract. World J Gastroenterol 15: 4016-4022, 2009.

20. Tarnawski AS: Cellular and molecular mechanisms of gastrointestinal ulcer healing. Dig Dis Sci 50 (Suppl 1): S24-S33, 2005.

21. Tarnawski A, Szabo IL, Husain SS and Soreghan B: Regeneration of gastric mucosa during ulcer healing is triggered by growth factors and signal transduction pathways. J Physiol Paris 95: $337-344,2001$.

22. Tarnawski AS and Ahluwalia A: Molecular mechanisms of epithelial regeneration and neovascularization during healing of gastric and esophageal ulcers. Curr Med Chem 19: 16-27, 2012.

23. Okamoto R, Yajima T, Yamazaki M, Kanai T, Mukai M, Okamoto S, Ikeda Y, Hibi T, Inazawa J and Watanabe M: Damaged epithelia regenerated by bone marrow-derived cells in the human gastrointestinal tract. Nat Med 8: 1011-1017, 2002

24. Karam SM: Lineage commitment and maturation of epithelial cells in the gut. Front Biosci 4: D286-D298, 1999.

25. Helander HF and Poorkhalkali N: Parietal cell density during gastric ulcer healing in the rat. Scand J Gastroenterol 39: 20-26, 2004.

26. Farrell JJ, Taupin D, Koh TJ, Chen D, Zhao CM, Podolsky DK and Wang TC: TFF2/SP-deficient mice show decreased gastric proliferation, increased acid secretion, and increased susceptibility to NSAID injury. J Clin Invest 109: 193-204, 2002.

27. Liu L, Chiu PW, Lam PK, Poon CC, Lam CC, Ng EK and Lai PB: Effect of local injection of mesenchymal stem cells on healing of sutured gastric perforation in an experimental model. Br J Surg 102: e158-e168, 2015.

28. Chang Q, Yan L, Wang CZ, Zhang WH, Hu YZ and Wu BY: In vivo transplantation of bone marrow mesenchymal stem cells accelerates repair of injured gastric mucosa in rats. Chin Med J (Engl) 125: 1169-1174, 2012.

29. Maemura T, Shin M and Kinoshita M: Tissue engineering of the stomach. J Surg Res 183: 285-295, 2013.

30. Sato $\mathrm{T}$ and Clevers H: SnapShot: Growing organoids from stem cells. Cell 161: 1700-1700.e1, 2015.

31. Pulikkot S, Greish YE, Mourad AH and Karam SM: Establishment of a three-dimensional culture system of gastric stem cells supporting mucous cell differentiation using microfibrous polycaprolactone scaffolds. Cell Prolif 47: 553-563, 2014.

32. Elliott SN, Buret A, McKnight W, Miller MJ and Wallace JL: Bacteria rapidly colonize and modulate healing of gastric ulcers in rats. Am J Physiol 275: G425-G432, 1998.

33. Podolsky SH: Metchnikoff and the microbiome: Lancet 380: 1810-1811, 2012.

34. Lilly DM and Stillwell RH: Probiotics: Growth-promoting factors produced by microorganisms. Science 147: 747-748, 1965.

35. Hill C, Guarner F, Reid G, Gibson GR, Merenstein DJ, Pot B, Morelli L, Canani RB, Flint HJ, Salminen S, et al: Expert consensus document. The International Scientific Association for Probiotics and Prebiotics consensus statement on the scope and appropriate use of the term probiotic. Nat Rev Gastroenterol Hepatol 11: 506-514, 2014.

36. Wallace TC, Guarner F, Madsen K, Cabana MD, Gibson G, Hentges E and Sanders ME: Human gut microbiota and its relationship to health and disease. Nutr Rev 69: 392-403, 2011.

37. Bezkorovainy A: Probiotics: Determinants of survival and growth in the gut. AmJ Clin Nutr 73 (Suppl 2): S399-S405, 2001.

38. Isolauri E, Sütas Y, Kankaanpää P, Arvilommi H and Salminen S: Probiotics: Effects on immunity. Am J Clin Nutr 73 (Suppl 2): S444-S450, 2001

39. Hong WS, Chen YP and Chen MJ: The antiallergic effect of kefir lactobacilli. J Food Sci 75: H244-H253, 2010.

40. Cain AM and Karpa KD: Clinical utility of probiotics in inflammatory bowel disease. Altern Ther Health Med 17: 72-79, 2011.

41. Shyu PT, Oyong GG and Cabrera EC: Cytotoxicity of probiotics from Philippine commercial dairy products on cancer cells and the effect on expression of cfos and cjun early apoptotic-promoting genes and interleukin- $1 \beta$ and tumor necrosis factor- $\alpha$ proinflammatory cytokine genes. Biomed Res Int 2014: 491740, 2014. 
42. Lam EK, Yu L, Wong HP, Wu WK, Shin VY, Tai EK, So WH, Woo PC and Cho CH: Probiotic Lactobacillus rhamnosus GG enhances gastric ulcer healing in rats. Eur J Pharmacol 565: 171-179, 2007

43. Uchida M and Kurakazu K: Yogurt containing Lactobacillus gasseri OLL2716 exerts gastroprotective action against acute gastric lesion and antral ulcer in rats. J Pharmacol Sci 96: 84-90, 2004.

44. Uchida M, Shimizu K and Kurakazu K: Yogurt containing Lactobacillus gasseri OLL 2716 (LG21 yogurt) accelerated the healing of acetic acid-induced gastric ulcer in rats. Biosci Biotechnol Biochem 74: 1891-1894, 2010.

45. Singh PK and Kaur IP: Synbiotic (probiotic and ginger extract) loaded floating beads: A novel therapeutic option in an experimental paradigm of gastric ulcer. J Pharm Pharmacol 64: 207-217, 2012

46. Singh PK, Deol PK and Kaur IP: Entrapment of Lactobacillus acidophilus into alginate beads for the effective treatment of cold restraint stress induced gastric ulcer. Food Funct 3: 83-90, 2012.

47. Dharmani P, De Simone $C$ and Chadee K: The probiotic mixture VSL\#3 accelerates gastric ulcer healing by stimulating vascular endothelial growth factor. PLoS One 8: 58671, 2013.

48. Lam EK, Tai EK, Koo MW, Wong HP, Wu WK, Yu L, So WH, Woo PC and Cho CH: Enhancement of gastric mucosal integrity by Lactobacillus rhamnosus GG. Life Sci 80: 2128-2136, 2007.

49. Timmerman HM, Koning CJ, Mulder L, Rombouts FM and Beynen AC: Monostrain, multistrain and multispecies probiotics - A comparison of functionality and efficacy. Int J Food Microbiol 96: 219-233, 2004

50. Flatley EA, Wilde AM and Nailor MD: Saccharomyces boulardii for the prevention of hospital onset Clostridium difficile infection. J Gastrointestin Liver Dis 24: 21-24, 2015.

51. Girard P, Coppé MC, Pansart Y and Gillardin JM: Gastroprotective effect of Saccharomyces boulardii in a rat model of ibuprofen-induced gastric ulcer. Pharmacology 85: 188-193, 2010.

52. Sakarya S and Gunay N: Saccharomyces boulardii expresses neuraminidase activity selective for $\alpha 2,3$-linked sialic acid that decreases Helicobacter pylori adhesion to host cells. APMIS 122: 941-950, 2014.

53. Aragon G, Graham DB, Borum M and Doman DB: Probiotic therapy for irritable bowel syndrome. Gastroenterol Hepatol (NY) 6: 39-44, 2010.

54. Brenner DM, Moeller MJ, Chey WD and Schoenfeld PS: The utility of probiotics in the treatment of irritable bowel syndrome: A systematic review. Am J Gastroenterol 104: 1033-1050, 2009.

55. Moayyedi P, Ford AC, Talley NJ, Cremonini F, Foxx-Orenstein AE, Brandt LJ and Quigley EM: The efficacy of probiotics in the treatment of irritable bowel syndrome: A systematic review. Gut 59: 325-332, 2010.

56. Ki Cha B, Mun Jung S, Hwan Choi C, Song ID, Woong Lee H, Joon Kim H, Hyuk J, Kyung Chang S, Kim K, Chung WS and Seo JG: The effect of a multispecies probiotic mixture on the symptoms and fecal microbiota in diarrhea-dominant irritable bowel syndrome: A randomized, double-blind, placebo-controlled trial. J Clin Gastroenterol 46: 220-227, 2012.

57. Lyra A, Krogius-Kurikka L, Nikkilä J, Malinen E, Kajander K, Kurikka K, Korpela R and Palva A: Effect of a multispecies probiotic supplement on quantity of irritable bowel syndrome-related intestinal microbial phylotypes. BMC Gastroenterol 10: 110, 2010.

58. Fuochi V, Petronio GP, Lissandrello E and Furneri PM: Evaluation of resistance to low $\mathrm{pH}$ and bile salts of human Lactobacillus spp. isolates. Int J Immunopathol Pharmacol 28: 426-433, 2015.

59. Pochart P, Marteau P, Bouhnik Y, Goderel I, Bourlioux P and Rambaud JC: Survival of bifidobacteria ingested via fermented milk during their passage through the human small intestine: An in vivo study using intestinal perfusion. Am J Clin Nutr 55: 78-80, 1992.

60. Lankaputhra WEV and Shah NP: Survival of Lactobacillus acidophilus and Bifidobacterium in the presence of acid and bile salts. Cult Dairy Prod J 30: 2-7, 1995.

61. Costello M: Probiotic foods. In: Foodpro-93: International Food Processing Machinery and Technology Exhibition and Conference, Sydney Convention \& Exhibition Centre, Australia, July 12-14 1993.

62. Clark PA, Cotton LN and Martin JH: Selection of Bifidobacterium spp. for use as dietary adjuncts in cultured dairy foods: II. Tolerance to simulated $\mathrm{pH}$ of human stomachs. Cult Dairy Prod J 28: 11-14, 1993.
63. Jacobsen CN, Rosenfeldt Nielsen V, Hayford AE, Møller PL, Michaelsen KF, Paerregaard A, Sandström B, Tvede M and Jakobsen M: Screening of probiotic activities of forty-seven strains of Lactobacillus spp. by in vitro techniques and evaluation of the colonization ability of five selected strains in humans. Appl Environ Microbiol 11: 4949-4956, 1999.

64. Lick S, Drescher K and Heller JK: Survival of Lactobacillus delbrueckii subsp. bulgaricus and Streptococcus thermophilus in the terminal ileum of fistulated Göttingen minipigs. Appl Environ Microbiol 67: 4137-4143, 2001.

65. Cotter PD and Hill C: Surviving the acid test: Responses of gram-positive bacteria to low $\mathrm{pH}$. Microbiol Mol Biol Rev 67: 429-453, 2003.

66. Fortier LC, Tourdot-Maréchal R, Diviès C, Lee BH and Guzzo J: Induction of Oenococcus oeni $\mathrm{H}^{+}$-ATPase activity and mRNA transcription under acidic conditions. FEMS Microbiol Lett 222: $165-169,2003$

67. Rius N, Solé M, Francis A and Lorén JG: Buffering capacity and membrane $\mathrm{H}^{+}$conductance of lactic acid bacteria. FEMS Microbiol Lett 120: 291-296, 1994.

68. Charalampopoulos D, Pandiella SS and Webb C: Evaluation of the effect of malt, wheat and barley extracts on the viability of potentially probiotic lactic acid bacteria under acidic conditions. Int J Food Microbiol 82: 133-141, 2003

69. Corcoran BM, Stanton C, Fitzgerald GF and Ross RP: Survival of probiotic lactobacilli in acidic environments is enhanced in the presence of metabolizable sugars. Appl Environ Microbiol 71: 3060-3067, 2005.

70. Haghshenas B, Abdullah N, Nami Y, Radiah D, Rosli R and Yari Khosroushahi A: Microencapsulation of probiotic bacteria Lactobacillusplantarum $15 \mathrm{HN}$ usingalginate-psyllium-fenugreek polymeric blends. J Appl Microbiol 118: 1048-1057, 2015.

71. Chen S, Zhao Q, Ferguson LR, Shu Q, Weir I and Garg S: Development of a novel probiotic delivery system based on microencapsulation with protectants. Appl Microbiol Biotechnol 93: 1447-1457, 2012.

72. Kailasapathy K: Microencapsulation of probiotic bacteria: Technology and potential applications. Curr Issues Intest Microbiol 3: 39-48, 2002.

73. Villena MJ, Lara-Villoslada F, Martínez MA and Hernández ME: Development of gastro-resistant tablets for the protection and intestinal delivery of Lactobacillus fermentum CECT 5716. Int J Pharm 487: 314-319, 2015

74. Mei L, He F, Zhou RQ, Wu CD, Liang R, Xie R, Ju XJ, Wang W and Chu LY: Novel intestinal-targeted Ca-alginate-based carrier for $\mathrm{pH}$-responsive protection and release of lactic acid bacteria. ACS Appl Mater Interfaces 6: 5962-5970, 2014.

75. Zhao Q, Lee SJ, Mutukumira AN, Maddox I and Shu Q: Viability and delivery of immobilised Lactobacillus reuteri DPC16 within calcium alginate gel systems during sequential passage through simulated gastrointestinal fluids. Benef Microbes 2: 129-138, 2011.

76. Adams CA: The probiotic paradox: Live and dead cells are biological response modifiers. Nutr Res Rev 23: 37-46, 2010.

77. Sashihara T, Sueki N and Ikegami S: An analysis of the effectiveness of heat-killed lactic acid bacteria in alleviating allergic diseases. J Dairy Sci 89: 2846-2855, 2006.

78. Zhang L, Nan L, Caicedo R and Neu J: Alive and dead Lactobacillus rhamnosus $\mathrm{GG}$ decrease tumor necrosis factor-alpha-induced interleukin-8 production in Caco-2 cells. J Nutr 135: 1752-1756, 2005.

79. Taverniti V and Guglielmetti S: The immunomodulatory properties of probiotic microorganisms beyond their viability (ghost probiotics: Proposal of paraprobiotic concept). Genes Nutr 6 : 261-274, 2011.

80. Sakai Y, Tsukahara T, Bukawa W, Matsubara N and Ushida K: Cell preparation of Enterococcus faecalis strain EC-12 prevents vancomycin-resistant enterococci colonization in the cecum of newly hatched chicks. Poult Sci 85: 273-277, 2006

81. Marin ML, Lee JH, Murtha J, Ustunol Z and Pestka JJ: Differential cytokine production in clonal macrophage and T-cell lines cultured with bifidobacteria. J Dairy Sci 80: 2713-2720, 1997.

82. Wagner RD, Pierson C, Warner T, Dohnalek M, Hilty M and Balish E: Probiotic effects of feeding heat-killed Lactobacillus acidophilus and Lactobacillus casei to Candida albicans-colonized immunodeficient mice. J Food Prot 63: 638-644, 2000.

83. Rachmilewitz D, Katakura K, Karmeli F, Hayashi T, Reinus C, Rudensky B, Akira S, Takeda K, Lee J, Takabayashi K and Raz E: Toll-like receptor 9 signaling mediates the anti-inflammatory effects of probiotics in murine experimental colitis. Gastroenterology 126: 520-528, 2004 
84. Orlando A, Refolo MG, Messa C, Amati L, Lavermicocca P, Guerra V and Russo F: Antiproliferative and proapoptotic effects of viable or heat-killed Lactobacillus paracase IMPC2.1 and Lactobacillus rhamnosus GG in HGC-27 gastric and DLD-1 colon cell lines. Nutr Cancer 64: 1103-1111, 2012.

85. Sanders ME, Guarner F, Guerrant R, Holt PR, Quigley EM Sartor RB, Sherman PM and Mayer EA: An update on the use and investigation of probiotics in health and disease. Gut 62 787-796, 2013

86. Marchesi JR, Adams DH, Fava F, Hermes GD, Hirschfield GM, Hold G, Quraishi MN, Kinross J, Smidt H, Tuohy KM, et al: The gut microbiota and host health: A new clinical frontier. Gut 65: 330-339, 2016.

87. Kumar M, Nagpal R, Kumar R, Hemalatha R, Verma V, Kumar A, Chakraborty C, Singh B, Marotta F, Jain S and Yadav H: Cholesterol-lowering probiotics as potential biotherapeutics for metabolic diseases. Exp Diabetes Res 2012: 902917 2012

88. Tsai TY, Chen LY and Pan TM: Effect of probiotic-fermented, genetically modified soy milk on hypercholesterolemia in hamsters. J Microbiol Immunol Infect 47: 1-8, 2014.

89. Pereira DI and Gibson GR: Cholesterol assimilation by lactic acid bacteria and bifidobacteria isolated from the human gut. Appl Environ Microbiol 68: 4689-4693, 2002

90. Kadooka Y, Sato M, Imaizumi K, Ogawa A, Ikuyama K, Akai Y, Okano M, Kagoshima M and Tsuchida T: Regulation of abdominal adiposity by probiotics (Lactobacillus gasseri SBT2055) in adults with obese tendencies in a randomized controlled trial. Eur J Clin Nutr 64: 636-643, 2010.

91. Yoda K, Sun X, Kawase M, Kubota A, Miyazawa K, Harata G, Hosoda M, Hiramatsu M, He F and Zemel MB: A combination of probiotics and whey proteins enhances anti-obesity effects of calcium and dairy products during nutritional energy restriction in aP2-agouti transgenic mice. Br J Nutr 113: $1689-1696,2015$

92. Kim SH, Huh CS, Choi ID, Jeong JW, Ku HK, Ra JH, Kim TY, Kim GB, Sim JH and Ahn YT: The anti-diabetic activity of Bifidobacterium lactis HY8101 in vitro and in vivo. J Appl Microbiol 117: 834-845, 2014

93. Moroti C, Souza Magri LF, de Rezende Costa M, Cavallini DC and Sivieri K: Effect of the consumption of a new symbiotic shake on glycemia and cholesterol levels in elderly people with type 2 diabetes mellitus. Lipids Health Dis 11:29, 2012.

94. Huang Y, Wang J, Quan G, Wang X, Yang L and Zhong L: Lactobacillus acidophilus ATCC 4356 prevents atherosclerosis via inhibition of intestinal cholesterol absorption in apolipoprotein E-knockout mice. Appl Environ Microbiol 80: 7496-7504, 2014

95. Aihara K, Kajimoto O, Hirata H, Takahashi R and Nakamura Y: Effect of powdered fermented milk with Lactobacillus helveticus on subjects with high-normal blood pressure or mild hypertension. J Am Coll Nutr 24: 257-265, 2005.

96. Rashid SK, Idris-Khodja N, Auger C, Alhosin M, Boehm N, Oswald-Mammosser M and Schini-Kerth VB: Probiotics (VSL\#3) prevent endothelial dysfunction in rats with portal hypertension: Role of the angiotensin system. PLoS One 9: e97458, 2014

97. Fotiadis CI, Stoidis CN, Spyropoulos BG and Zografos ED: Role of probiotics, prebiotics and synbiotics in chemoprevention for colorectal cancer. World J Gastroenterol 14: 6453-6457, 2008.

98. Sobhani I, Amiot A, Le Baleur Y, Levy M, Auriault ML, Van Nhieu JT and Delchier JC: Microbial dysbiosis and colon carcinogenesis: Could colon cancer be considered a bacteria-related disease? Therap Adv Gastroenterol 6: 215-229, 2013.

99. Zhang M, Fan X, Fang B, Zhu C, Zhu J and Ren F: Effects of Lactobacillus salivarius Ren on cancer prevention and intestinal microbiota in 1,2-dimethylhydrazine-induced rat model. J Microbiol 53: 398-405, 2015 .

100. Chen ZF, Ai LY, Wang JL, Ren LL, Yu YN, Xu J, Chen HY, Yu J, Li M, Qin WX, et al: Probiotics Clostridium butyricum and Bacillus subtilis ameliorate intestinal tumorigenesis. Future Microbiol 10: 1433-1445, 2015.

101. Russo F, Linsalata M and Orlando A: Probiotics against neoplastic transformation of gastric mucosa: Effects on cell proliferation and polyamine metabolism. World J Gastroenterol 20: 13258-13272, 2014

102. Cousin FJ, Jouan-Lanhouet S, Dimanche-Boitrel MT, Corcos L and Jan G: Milk fermented by Propionibacterium freudenreichii induces apoptosis of HGT-1 human gastric cancer cells. PLoS One 7: e31892,2012.
103. Linsalata M, Cavallini A, Messa C, Orlando A, Refolo MG and Russo F: Lactobacillus rhamnosus GG influences polyamine metabolism in HGC-27 gastric cancer cell line: A strategy toward nutritional approach to chemoprevention of gastric cancer. Curr Pharm Des 16: 847-853, 2010.

104. Haghshenas B, Abdullah N, Nami Y, Radiah D, Rosli R and Khosroushahi AY: Different effects of two newly-isolated probiotic Lactobacillus plantarum $15 \mathrm{HN}$ and Lactococcus lactis subsp. Lactis 44Lac strains from traditional dairy products on cancer cell lines. Anaerobe 30: 51-59, 2014.

105. Chitapanarux I, Chitapanarux T, Traisathit P, Kudumpee S, Tharavichitkul E and Lorvidhaya V: Randomized controlled trial of live Lactobacillus acidophilus plus Bifidobacterium bifidum in prophylaxis of diarrhea during radiotherapy in cervical cancer patients. Radiat Oncol 5: 31, 2010.

106. Osterlund P, Ruotsalainen T, Korpela R, Saxelin M, Ollus A, Valta P, Kouri M, Elomaa I and Joensuu H: Lactobacillus supplementation for diarrhoea related to chemotherapy of colorectal cancer: A randomised study. Br J Cancer 97: 1028-1034, 2007

107. Crouzet L, Rigottier-Gois L and Serror P: Potential use of probiotic and commensal bacteria as non-antibiotic strategies against vancomycin-resistant enterococci. FEMS Microbiol Lett 362: fnv012, 2015.

108. Gill EE, Franco OL and Hancock RE: Antibiotic adjuvants: Diverse strategies for controlling drug-resistant pathogens. Chem Biol Drug Des 85: 56-78, 2015.

109. Cano-Garrido O, Seras-Franzoso J and Garcia-Fruitós E: Lactic acid bacteria: Reviewing the potential of a promising delivery live vector for biomedical purposes. Microb Cell Fact 14: 137, 2015.

110. Mohamadzadeh M and Owen JL: Reprogramming intestinal immunity is the answer to induced pathogenic inflammation. Immunotherapy 3: 1415-1417, 2011.

111. Wells JM and Mercenier A: Mucosal delivery of therapeutic and prophylactic molecules using lactic acid bacteria. Nat Rev Microbiol 6: 349-362, 2008

112. Bermúdez-Humarán LG: Lactococcus lactis as a live vector for mucosal delivery of therapeutic proteins. Hum Vaccin 5: 264-267, 2009.

113. Marelli B, Perez AR, Banchio C, de Mendoza D and Magni C: Oral immunization with live Lactococcus lactis expressing rotavirus VP8 subunit induces specific immune response in mice. J Virol Methods 175: 28-37, 2011

114. Konturek PC, Sliwowski Z, Koziel J, Ptak-Belowska A, Burnat G, Brzozowski T and Konturek SJ: Probiotic bacteria Escherichia coli strain Nissle 1917 attenuates acute gastric lesions induced by stress. J Physiol Pharmacol 60 (Suppl 6): S41-S48, 2009

115. Spivak MIa, Lazarenko LM, Falalieieva TM, Virchenko OV and Neporada KS: Prophylactic effect of probiotic strains Bifidobacterium animalis VKL and VKB on stress-induced lesions in the gastric mucosa of rats. Fiziol Zh 59: 23-30, 2013 (In Ukrainian).

116. Nagaoka M, Hashimoto $S$, Watanabe $T$, Yokokura $T$ and Mori Y: Anti-ulcer effects of lactic acid bacteria and their cell wall polysaccharides. Biol Pharm Bull 17: 1012-1017, 1994.

117. Viggiano D, Ianiro G, Vanella G, Bibbò S, Bruno G, Simeone G and Mele G: Gut barrier in health and disease: Focus on childhood. Eur Rev Med Pharmacol Sci 19: 1077-1085, 2015.

118. Laine L, Takeuchi K and Tarnawski A: Gastric mucosal defense and cytoprotection: Bench to bedside. Gastroenterology 135: 41-60, 2008.

119. Takeeda M, Hayashi Y, Yamato M, Murakami M and Takeuchi K: Roles of endogenous prostaglandins and cyclooxygenase izoenzymes in mucosal defense of inflamed rat stomach. J Physiol Pharmacol 55: 193-205, 2004.

120. Boirivant $\mathrm{M}$ and Strober $\mathrm{W}$ : The mechanism of action of probiotics. Curr Opin Gastroenterol 23: 679-692, 2007.

121. Vieira AT, Teixeira MM and Martins FS: The role of probiotics and prebiotics in inducing gut immunity. Front Immunol 4: 445, 2013.

122. Jones SE and Versalovic J: Probiotic Lactobacillus reuteri biofilms produce antimicrobial and anti-inflammatory factors. BMC Microbiol 9: 35, 2009.

123. Coman MM, Verdenelli MC, Cecchini C, Silvi S, Orpianesi C, Boyko $\mathrm{N}$ and Cresci A: In vitro evaluation of antimicrobial activity of Lactobacillus rhamnosus IMC $501^{\circledR}$, Lactobacillus paracasei IMC $502^{\circledR}$ and $\mathrm{SYNBIO}^{\circledR}$ against pathogens. J Appl Microbiol 117: 518-527, 2014 
124. Bernet MF, Brassart D, Neeser JR and Servin AL: Lactobacillus acidophilus LA 1 binds to cultured human intestinal cell lines and inhibits cell attachment and cell invasion by enterovirulent bacteria. Gut 35: 483-489, 1994

125. Mukai T, Asasaka T, Sato E, Mori K, Matsumoto M and Ohori H: Inhibition of binding of Helicobacter pylori to the glycolipid receptors by probiotic Lactobacillus reuteri. FEMS Immunol Med Microbiol 32: 105-110, 2002.

126. Lin YP, Thibodeaux CH, Peña JA, Ferry GD and Versalovic J: Probiotic Lactobacillus reuteri suppress proinflammatory cytokines via c-Jun. Inflamm Bowel Dis 14: 1068-1083, 2008.

127. Takagi A, Matsuzaki T, Sato M, Nomoto K, Morotomi M and Yokokura T: Enhancement of natural killer cytotoxicity delayed murine carcinogenesis by a probiotic microorganism. Carcinogenesis 22: 599-605, 2001

128. Haller D, Bode C, Hammes WP, Pfeifer AM, Schiffrin EJ and Blum S: Non-pathogenic bacteria elicit a differential cytokine response by intestinal epithelial cell/leucocyte co-cultures. Gut 47: 79-87, 2000

129. Borchers AT, Selmi C, Meyers FJ, Keen CL and Gershwin ME: Probiotics and immunity. J Gastroenterol 44: 26-46, 2009.

130. Madsen K, Cornish A, Soper P, McKaigney C, Jijon H, Yachimec C, Doyle J, Jewell L and De Simone C: Probiotic bacteria enhance murine and human intestinal epithelial barrier function. Gastroenterology 121: 580-591, 2001.

131. Gotteland M, Cruchet S and Verbeke S: Effect of Lactobacillus ingestion on the gastrointestinal mucosal barrier alterations induced by indomethacin in humans. Aliment Pharmacol Ther 15: 11-17, 2001.

132. Rao RK and Samak G. Protection and Restitution of Gut Barrier by Probiotics: Nutritional and clinical implications. Curr Nutr Food Sci 9: 99-107, 2013.

133. Gomi A, Harima-Mizusawa N, Shibahara-Sone H, Kano M, Miyazaki K and Ishikawa F: Effect of Bifidobacterium bifidum BF-1 on gastric protection and mucin production in an acute gastric injury rat model. J Dairy Sci 96: 832-837, 2013.

134. Dai C, Zhao DH and Jiang M: VSL\#3 probiotics regulate the intestinal epithelial barrier in vivo and in vitro via the p38 and ERK signaling pathways. Int J Mol Med 29: 202-208, 2012.

135. Mennigen R, Nolte K, Rijcken E, Utech M, Loeffler B Senninger $\mathrm{N}$ and Bruewer M: Probiotic mixture VSL\#3 protects the epithelial barrier by maintaining tight junction protein expression and preventing apoptosis in a murine model of colitis. Am J Physiol Gastrointest Liver Physiol 296: G1140-G1149, 2009

136. Wang FY, Liu JM, Luo HH, Liu AH and Jiang Y: Potential protective effects of Clostridium butyricum on experimental gastric ulcers in mice. World J Gastroenterol 21: 8340-8351, 2015.

137. Virchenko OV, Falalyeyeva TM, Beregova TV, Spivak MY, Lazarenko LM and Demchenko OM: Effects of mono-, polyand composite probiotics on the ulceration caused by restraint stress. Fiziol Zh 61: 35-41, 2015 (In Ukrainian).

138. Virchenko OV,Falalyeyeva TM, Beregova TV and Maryana SY: The multistrain probiotic enhances the healing process of stress-induced lesions of the gastric mucosa of rats. RJPBCS 6: 249, 2015.

139. Wang JY, Yamasaki S, Takeuchi K and Okabe S: Delayed healing of acetic acid-induced gastric ulcers in rats by indomethacin. Gastroenterology 96: 393-402, 1989.

140. Santucci L, Fiorucci S, Di Matteo FM and Morelli A: Role of tumor necrosis factor alpha release and leukocyte margination in indomethacin-induced gastric injury in rats. Gastroenterology 108: 393-401, 1995.

141. Yoshikawa T, Takano H, Naito Y, Oyamada H, Ueda S and Kondo M: Augmentative effects of tumor necrosis factor-alpha (human, natural type) on polymorphonuclear leukocyte-derived superoxide generation induced by various stimulants. Int J Immunopharmacol 14: 1391-1398, 1992.

142. Senol A, Işler M, Karahan AG, Kiliç GB, Kuleaşan H, Gören I, Saritaş U, Kaya S, Cirıs M, Aktürk O, et al: Effect of probiotics on aspirin-induced gastric mucosal lesions. Turk J Gastroenterol 22: 18-26, 2011.

143. Senol A, Isler M, Karahan AG, Kilic GB, Kuleasan H, Kaya S, Keskin M, Goren I, Saritas U, Aridogan BC and Delibas N: Preventive effect of probiotics and $\alpha$-tocopherol on ethanol-induced gastric mucosal injury in rats. J Med Food 14: 173-179, 2011.

144. Allen A and Pearson JP: Mucus glycoproteins of the normal gastrointestinal tract. Eur J Gastroenterol Hepatol 5: 193-199, 1993.
145. Wong WM, Poulsom R and Wright NA: Trefoil peptides. Gut 44: 890-895, 1999.

146. Phillipson M, Johansson ME, Henriksnäs J, Petersson J, Gendler SJ, Sandler S, Persson AE, Hansson GC and Holm L: The gastric mucus layers: Constituents and regulation of accumulation. Am J Physiol Gastrointest Liver Physiol 295: G806-G812, 2008

147. Corfield AP, Carroll D, Myerscough N and Probert CS Mucins in the gastrointestinal tract in health and disease. Front Biosci 6: D1321-D1357, 2001.

148. Singh PK and Hollingsworth MA: Cell surf ace-associated mucins in signaltransduction. Trends Cell Biol 16:467-476,2006.

149. Karam SM, Tomasetto $C$ and Rio MC: Trefoil factor 1 is required for the commitment programme of mouse oxyntic epithelial progenitors. Gut 53: 1408-1415, 2004.

150. Ren JL, Luo JY, Lu YP, Wang L and Shi HX: Relationship between trefoil factor 1 expression and gastric mucosa injuries and gastric cancer. World J Gastroenterol 11: 2674-2677, 2005.

151. Fu T, Kalbacher $\mathrm{H}$ and Hoffmann W: TFF1 is differentially expressed in stationary and migratory rat gastric epithelial cells (RGM-1) after in vitro wounding: Influence of TFF1 RNA interference on cell migration. Cell Physiol Biochem 32: 997-1010, 2013

152. Atuma C, Strugala V, Allen A and Holm L: The adherent gastrointestinal mucus gel layer: Thickness and physical state in vivo. Am J Physiol Gastrointest Liver Physiol 280: G922-G929, 2001.

153. Kaunitz JD: Barrier function of gastric mucus. Keio J Med 2: 63-68, 1999.

154. Mattar AF, Teitelbaum DH, Drongowski RA, Yongyi F, Harmon CM and Coran AG: Probiotics up-regulate MUC-2 mucin gene expression in a Caco-2 cell-culture model. Pediatr Surg Int 18: 586-590, 2002.

155. Kim Y, Kim SH, Whang KY, Kim YJ and Oh S: Inhibition of Escherichia coli $\mathrm{O} 157: \mathrm{H} 7$ attachment by interactions between lactic acid bacteria and intestinal epithelial cells. J Microbiol Biotechnol 18: 1278-1285, 2008.

156. Otte JM and Podolsky DK: Functional modulation of enterocytes by gram-positive and gram-negative microorganisms. Am J Physiol Gastrointest Liver Physiol 286: G613-G626, 2004

157. Caballero-Franco C, Keller K, De Simone C and Chadee K: The VSL\#3 probiotic formula induces mucin gene expression and secretion in colonic epithelial cells. Am J Physiol Gastrointest Liver Physiol 292: G315-G322, 2007.

158. Ouwehand AC, Salminen S, Tölkkö S, Roberts P, Ovaska J and Salminen E: Resected human colonic tissue: New model for characterizing adhesion of lactic acid bacteria. Clin Diagn Lab Immunol 9: 184-186, 2002

159. Nishiyama K, Nakamata K, Ueno S, Terao A, Aryantini NP, Sujaya IN, Fukuda K, Urashima T, Yamamoto Y and Mukai T: Adhesion properties of Lactobacillus rhamnosus mucus-binding factor to mucin and extracellular matrix proteins. Biosci Biotechnol Biochem 79: 271-279, 2015.

160. Karam SM and Leblond CP: Dynamics of epithelial cells in the corpus of the mouse stomach. I.dentification of proliferative cell types and pinpointing of the stem cell. Anat Rec 236: 259-279, 1993

161. Karam SM, Straiton T, Hassan WM and Leblond CP: Defining epithelial cell progenitors in the human oxyntic mucosa. Stem Cells 21: 322-336, 2003.

162. Karam SM: A focus on parietal cells as a renewing cell population. World J Gastroenterol 16: 538-546, 2010.

163. Risau W: Mechanisms of angiogenesis Nature 386: 671-674, 1997.

164. Taketani Y, Kinugasa K, Kitajima R, Nishiumi S, Ashida H, Nakamura H, Fujita T, Kanzaki K, Masutani H and Yodoi J: Protective effects of oral administration of yeast thioredoxin against gastric mucosal injury. Biosci Biotechnol Biochem 78: 1221-1230, 2014

165. Schöttker B, Adamu MA, Weck MN and Brenner $\mathrm{H}$ : Helicobacter pylori infection is strongly associated with gastric and duodenal ulcers in a large prospective study. Clin Gastroenterol Hepatol 10: 487-493.e1, 2012.

166. Cover TL and Blaser MJ: Helicobacter pylori in health and disease. Gastroenterology 136: 1863-1873, 2009.

167. Vergara M,Catalán M, Gisbert JP and Calvet X: Meta-analysis: Role of Helicobacter pylori eradication in the prevention of peptic ulcer in NSAID users. Aliment Pharmacol Ther 21: $1411-1418,2005$ 
168. Malfertheiner P, Selgrad M and Bornschein J. Helicobacter pylori: Clinical management. Curr Opin Gastroenterol 28: 608-614, 2012

169. Giorgio F, Principi M, De Francesco V, Zullo A, Losurdo G, Di Leo A and Ierardi E: Primary clarithromycin resistance to Helicobacter pylori: Is this the main reason for triple therapy failure? World J Gastrointest Pathophysiol 4: 43-46, 2013

170. Graham DY and Fischbach L: Helicobacter pylori treatment in the era of increasing antibiotic resistance. Gut 59: 1143-1153, 2010.

171. Papastergiou V,Georgopoulos SD and Karatapanis S: Treatment of Helicobacter pylori infection: Meeting the challenge of antimicrobial resistance. World J Gastroenterol 20: 9898-9911, 2014.

172. Tongtawee T,Dechsukhum C, Leeanansaksiri W, Kaewpitoon S, Kaewpitoon N, Loyd RA, Matrakool L and Panpimanmas S: Improved Helicobacter pylori eradication rate of tailored triple therapy by adding Lactobacillus delbrueckii and Streptococcus thermophilus in northeast region of Thailand: A prospective randomized controlled clinical trial. Gastroenterol Res Pract 2015: 518018, 2015.

173. Johnson-Henry KC, Mitchell DJ, Avitzur Y, Galindo-Mata E, Jones NL and Sherman PM: Probiotics reduce bacterial colonization and gastric inflammation in $H$.pylori-infected mice. Dig Dis Sci 49: 1095-1102, 2004

174. Sheu BS, Wu JJ, Lo CY, Wu HW, Chen JH, Lin YS and Lin MD: Impact of supplement with Lactobacillus- and Bifidobacterium-containing yogurt on triple therapy for Helicobacter pylori eradication. Aliment Pharmacol Ther 16: 1669-1675, 2002.

175. Ushiyama A, Tanaka K, Aiba Y, Shiba T, Takagi A, Mine T and Koga Y: Lactobacillus gasseri OLL2716 as a probiotic in clarithromycin-resistant Helicobacter pylori infection. J Gastroenterol Hepatol 18: 986-991, 2003.

176. Chenoll E, Casinos B, Bataller E, Astals P, Echevarría J, Iglesias JR, Balbarie P, Ramón D and Genovés S: Novel probiotic Bifidobacterium bifidum CECT 7366 strain active against the pathogenic bacterium Helicobacter pylori. Appl Environ Microbiol 77: 1335-1343, 2011.

177. Gotteland M and Cruchet S: Suppressive effect of frequent ingestion of Lactobacillus johnsonii La1 on Helicobacter pylori colonization in asymptomatic volunteers. J Antimicrob Chemother 51: 1317-1319, 2003.

178. Kabir AM, Aiba Y, Takagi A, Kamiya S, Miwa T and Koga Y: Prevention of Helicobacter pylori infection by lactobacilli in a gnotobiotic murine model. Gut 41: 49-55, 1997.

179. Lesbros-Pantoflickova D, Corthésy-Theulaz I and Blum AL Helicobacter pylori and probiotics. J Nutr 137 (3 Suppl 2): S812-S818, 2007.

180. Ruggiero P: Use of probiotics in the fight against Helicobacter pylori. World J Gastrointest Pathophysiol 5: 384-391, 2014

181. Yang YJ and Sheu BS: Probiotics-containing yogurts suppress Helicobacter pylori load and modify immune response and intestinal microbiota in the Helicobacter pylori-infected children. Helicobacter 17: 297-304, 2012.

182. Sgouras D, Maragkoudakis P, Petraki K, Martinez-Gonzalez B, Eriotou E, Michopoulos S, Kalantzopoulos G, Tsakalidou E and Mentis A: In vitro and in vivo inhibition of Helicobacter pylori by Lactobacillus casei strain Shirota. Appl Environ Microbiol 70: 518-526, 2004

183. Aiba Y, Nakano Y, Koga Y, Takahashi K and Komatsu Y: A highly acid-resistant novel strain of Lactobacillus johnsoni No. 1088 has antibacterial activity, including that against Helicobacter pylori, and inhibits gastrin-mediated acid production in mice. Microbiologyopen 4: 465-474, 2015.

184. Isobe H, Nishiyama A, Takano T, Higuchi W, Nakagawa S, Taneike I, Fukushima Y and Yamamoto T: Reduction of overall Helicobacter pylori colonization levels in the stomach of Mongolian gerbil by Lactobacillus johnsonii La1 (LC1) and its in vitro activities against $H$. pylori motility and adherence. Biosci Biotechnol Biochem 76: 850-852, 2012

185. Hsieh PS, Tsai YC, Chen YC, Teh SF, Ou CM and King VA: Eradication of Helicobacter pylori infection by the probiotic strains Lactobacillus johnsonii MH-68 and L. salivarius ssp. salicinius AP-32. Helicobacter 17: 466-477, 2012.
186. Chen X, Liu XM, Tian F, Zhang Q, Zhang HP, Zhang H and Chen W: Antagonistic activities of lactobacilli against Helicobacter pylori growth and infection in human gastric epithelial cells. J Food Sci 77: M9-M14, 2012.

187. Mack DR, Ahrne S, Hyde L, Wei S and Hollingsworth MA Extracellular MUC3 mucin secretion follows adherence of Lactobacillus strains to intestinal epithelial cells in vitro. Gut 52: 827-833, 2003

188. Thiraworawong T, Spinler JK, Werawatganon D, Klaikeaw N, Venable SF, Versalovic J and Tumwasorn S: Anti-inflammatory properties of gastric-derived Lactobacillus plantarum XB7 in the context of Helicobacter pylori infection. Helicobacter 19: 144-155, 2014.

189. Hwang SW, Kim N, Kim JM, Huh CS, Ahn YT, Park SH, Shin CM, Park JH, Lee MK, Nam RH, et al: Probiotic suppression of the $H$. pylori-induced responses by conjugated linoleic acids in a gastric epithelial cell line. Prostaglandins Leukot Essent Fatty Acids 86: 225-231, 2012.

190. Kim JM, Kim JS, Kim YJ, Oh YK, Kim IY, Chee YJ, Han JS and Jung HC: Conjugated linoleic acids produced by Lactobacillus dissociates IKK-gamma and Hsp90 complex in Helicobacter pylori-infected gastric epithelial cells. Lab Invest 88: 541-552, 2008

191. Lee JS, Paek NS, Kwon OS and Hahm KB: Anti-inflammatory actions of probiotics through activating suppressor of cytokine signaling (SOCS) expression and signaling in Helicobacter pylori infection: A novel mechanism. J Gastroenterol Hepatol 25: 194-202, 2010.

192. Mehling H and Busjahn A: Non-viable Lactobacillus reuteri DSMZ 17648 (Pylopass ${ }^{\mathrm{TM}}$ ) as a new approach to Helicobacter pylori control in humans. Nutrients 5: 3062-3073, 2013.

193. Holz C, Busjahn A, Mehling H, Arya S, Boettner M, Habibi H and Lang C: Significant reduction in Helicobacter pylori load in humans with non-viable Lactobacillus reuteri DSM17648: A pilot study. Probiotics Antimicrob Proteins 7: 91-100, 2015.

194. Hauser G, Salkic N, Vukelic K, JajacKnez A and Stimac D Probiotics for standard triple Helicobacter pylori eradication: A randomized, double-blind, placebo-controlled trial. Medicine (Baltimore) 94: e685, 2015.

195. Francavilla R, Polimeno L, Demichina A, Maurogiovanni G, Principi B, Scaccianoce G, Ierardi E, Russo F, Riezzo G, Di Leo A, et al: Lactobacillus reuteri strain combination in Helicobacter pylori infection: A randomized, double-blind, placebo-controlled study. J Clin Gastroenterol 48: 407-413, 2014.

196. Pantoflickova D, Corthésy-Theulaz I, Dorta G, Stolte M, Isler P, Rochat F, Enslen M and Blum AL: Favourable effect of regular intake of fermented milk containing Lactobacillus johnsoni on Helicobacter pylori associated gastritis. Aliment Pharmacol Ther 18: 805-813, 2003

197. Michetti P, Dorta G, Wiesel PH, Brassart D, Verdu E, Herranz M, Felley C, Porta N, Rouvet M, Blum AL and Corthésy-Theulaz I: Effect of whey-based culture supernatant of Lactobacillus acidophilus (johnsonii) La1 on Helicobacter pylori infection in humans. Digestion 60: 203-209, 1999.

198. Szajewska H, Horvath A and Piwowarczyk A: Meta-analysis: The effects of Saccharomyces boulardii supplementation on Helicobacter pylori eradication rates and side effects during treatment. Aliment Pharmacol Ther 32: 1069-1079, 2010

199. Zou J, Dong J and Yu X: Meta-analysis: Lactobacillus containing quadruple therapy versus standard triple first-line therapy for Helicobacter pylori eradication. Helicobacter 14: 97-107, 2009.

200. Hamilton-Miller JM: The role of probiotics in the treatment and prevention of Helicobacter pylori infection. Int J Antimicrob Agents 22: 360-366, 2003

201. Patel A, Shah N and Prajapati JB: Clinical application of probiotics in the treatment of Helicobacter pylori infection - a brief review. J Microbiol Immunol Infect 47: 429-437, 2014

202. Shane AL, Cabana MD, Vidry S, Merenstein D, Hummelen R, Ellis CL, Heimbach JT, Hempel S, Lynch SV, Sanders ME and Tancredi DJ: Guide to designing, conducting, publishing and communicating results of clinical studies involving probiotic applications in human participants. Gut Microbes 1: 243-253, 2010. 